Int. J. Dev. Biol. 53: 335-354 (2009)

doi: $10.1387 / \mathrm{ijdb} .082717 \mathrm{ph}$

\title{
Mechanisms of transcriptional repression by histone lysine methylation
}

\author{
PHILIP HUBLITZ\#, MAREIKE ALBERT\#\# and ANTOINE H.F.M. PETERS* \\ Friedrich Miescher Institute for Biomedical Research, Basel, Switzerland
}

\begin{abstract}
During development, covalent modification of both, histones and DNA contribute to the specification and maintenance of cell identity. Repressive modifications are thought to stabilize cell type specific gene expression patterns, reducing the likelihood of reactivation of lineage-unrelated genes. In this report, we review the recent literature to deduce mechanisms underlying Polycomb and H3K9 methylation mediated repression, and describe the functional interplay with activating H3K4 methylation. We summarize recent data that indicate a close relationship between GC density of promoter sequences, transcription factor binding and the antagonizing activities of distinct epigenetic regulators such as histone methyltransferases (HMTs) and histone demethylases (HDMs). Subsequently, we compare chromatin signatures associated with different types of transcriptional outcomes from stable repression to highly dynamic regulated genes, strongly suggesting that the interplay of different epigenetic pathways is essential in defining specific types of heritable chromatin and associated transcriptional states.
\end{abstract}

KEY WORDS: transcriptional control, histone lysine methylation, methyltransferase, demethylase, polycomb

Genetic and epigenetic mechanisms ensure that complex developmental programs are correctly executed. One important posttranslational modification that regulates transcriptional outcomes, genome integrity and cellular identity is histone lysine methylation. Defined methylation patterns are related to distinct functional readouts of chromosomal DNA. The initial discoveries of histone modifying enzymes lead to the postulation of the "histone code" hypothesis, whereby defined histone modifications, acting in a combinatorial or sequential fashion on one or multiple histone termini, specify the transcriptional state of a gene by recruitment of regulatory proteins. In this review, we discuss the indexing potential of histone lysine methylation in the light of how histone methyltransferases (HMTs) and histone demethylases (HDMs) are targeted to given promoter contexts, how the GC content of target promoters influences the regulatory response, and how the functional interplay between HMTs and HDMs ultimately defines transcriptional states. For in-depth discussions of the developmental functions of individual HMTs and HDMs, we refer the reader to recent reviews (Cloos et al., 2008; Martin and Zhang, 2005) (Fig. 1). We first summarize new insights gained by the recent epigenomic profiling studies of histone methylation and transcription factor occupancy in relation to transcriptional $\mathrm{ON}$ and OFF states. We mainly focus on the dynamics of activating H3K4 and repressive H3K27 methylation marks at promoter sequences. The genomic data serve as a foundation to understand the interrelationship between transcription factor and chromatin based pathways. We in-depth review the responsible classes of enzymes mediating those modifications and report on their functional importance. In a second part, we review two scenarios of dynamically controlled transcriptional systems, nuclear hormone receptor signaling, whose repression is largely based on $\mathrm{H} 3 \mathrm{~K} 9$ methylation, and the regulation of the cell division cycle, where senescence and proliferation are controlled by $\mathrm{H} 3 \mathrm{~K} 9$ and H3K27 methylation. Both systems are especially well characterized in terms of recruitment of histone modifying enzymes and

\footnotetext{
Abbreviations used in this paper: $\mathrm{AR}$, androgen receptor; $\mathrm{CpG}$, cytosineguanidine dinucleotide; ER, estrogen receptor; HDM, histone demethylase; HMT, histone methyltransferase; NHR, nuclear hormone receptor; PcG, polycomb group; PTM, post translational modification; RNAPII, DNAdependent RNA-polymerase II; TrxG, trithorax group; TSS, transcriptional start site.
}

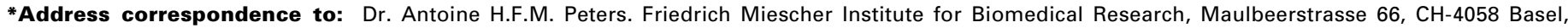
Switzerland. Tel: +41-61-697-8761. Fax: +41-61-697-3976. e-mail: antoine.peters@fmi.ch

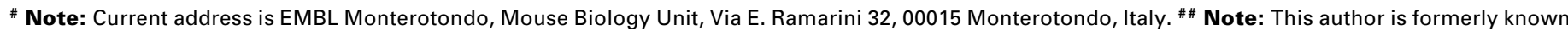

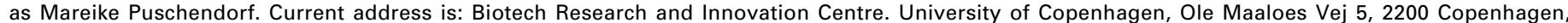
Denmark.
}

Published online: 28 April 2009.

ISSN: Online 1696-3547, Print 0214-6282

(C) 2009 UBC Press

Printed in Spain 
in combining several epigenetic pathways to achieve the desired transcriptional outcome.

\section{Transcriptional repression by H3K27 methylation}

\section{Bivalency of H3K4 and H3K27 methylation}

In mammals, recent genome-wide mapping studies of Polycomb Group (PcG) and Trithorax Group (TrxG) proteins and their marks, classically associated with repressed and active transcriptional states, respectively, revealed many novel target genes. These studies provide the framework to delineate mechanisms of targeting and gene regulation mediated by the different epigenetic modifiers. Three initial ChIP-chip studies in human and mouse ES cells (Bernstein et al., 2006a; Boyer et al., 2006; Lee et al., 2006b) showed that core components of the Polycomb Repressive Complex PRC1 (Rnf2, Phc1), PRC2 (Eed, Suz12) and H3K27me3 do not only colocalize to classical target genes (such as the four Hox clusters) but also to many other loci. Particularly genes coding for developmental regulators including homeodomain (DIx, Irx, Lhx, Pou, Pax, Six) and other transcription factors (such as Fox, Sox, Gata and Tbx) were highly overrepresented among PcG target genes. These proteins serve master regulatory functions in organogenesis and morphogenesis, pattern specification, cell differentiation, embryonic development and cell fate commitment (Boyer et al., 2006; Lee et al., $2006 b)$. PcG targets are generally repressed in ES cells and are preferentially activated during ES cell differentiation. In Eed and Suz12 gene deficient ES cells that lack detectable amounts of PRC2 complexes and H3K27me3, transcript levels of most PcG target genes were increased (Boyer et al., 2006; Lee et al., 2006b). These data suggested that Polycomb complexes are required for maintaining ES cell pluripotency and plasticity during embryonic development.

While studying genomic regions that harbor highly conserved non-coding elements, Bernstein and colleagues made a remarkable observation. They noticed that extended regions marked by $\mathrm{H} 3 \mathrm{~K} 27 \mathrm{me} 3$ were also marked by $\mathrm{H} 3 \mathrm{~K} 4 \mathrm{me} 3$, a histone modification normally associated with transcriptional activity (Bernstein et al., 2006a). Sequential ChIP experiments confirmed that identical alleles were labeled by both "repressive" and "activating" chromatin modifications, resulting in the term "bivalent domains". Genes within bivalent domains were largely repressed, to almost the same extent as genes that were marked by H3K27me3 alone. In contrast, genes only

Fig. 1. Overview of histone methylation processes. (A) Methylation of lysines H3K4 and H3K36 is generally correlated with transcriptional activity, and demethylation of $\mathrm{H} 3 \mathrm{~K} 4$ is required for effective silencing. The specificities of $\mathrm{H} 3 \mathrm{~K} 4$ and H3K36 HMTs are not unambiguously clear yet. (B) Methylation of H3K9 and H3K27 are hallmarks of transcriptional repression, and the antagonizing HDMs are categorized as transcriptional co-activators. H3K9me3 is a hallmark of constitutive heterochromatin; H3K27me3 is the readout of $P C G$ mediated silencing. (C) In the tail of histone H4, only $\mathrm{K} 2 \mathrm{O}$ is targeted by HMTs. H4K20me1 correlates with ongoing transcription, whereas H4K2Ome3 is an integral part of heterochromatin mediated silencing. (D)Dot1 $\mathrm{L}$ is the only HMT known to target H3K79 in the globular domain of H3. No HDM is known to target either H4K2O or H3K79. HMTs are indicated above the histone tails, HDMs are below, and hexagons represent the respective methylation status. Asterisks $\left({ }^{*}\right)$ indicate enzymes that target multiple lysine residues. 
associated with $\mathrm{H} 3 \mathrm{~K} 4 \mathrm{me} 3$ were highly expressed (Bernstein et al., 2006a) (Fig. 2A). These results indicate that in bivalent domains the repressive $\mathrm{H} 3 \mathrm{~K} 27 \mathrm{me} 3$ state generally overrules the activating effect of $\mathrm{H} 3 \mathrm{~K} 4 \mathrm{me} 3$. Interestingly, after differentiation, bivalency at promoters of transcriptional regulators was resolved into either regions exclusively marked by either $\mathrm{H} 3 \mathrm{~K} 4 \mathrm{me} 3$ or H3K27me3. Based on these observations, Bernstein et al. suggested that bivalent domains are largely ES cell specific, serving to silence developmental genes while keeping them poised for activation or repression during later development (Fig. 2A, parts $2,4,5)$.

Using genome-wide epigenomic profiling strategies, several other groups subsequently showed that bivalency is not restricted to ES cells but also exists in various progenitor and differentiated cell types (Barski et al., 2007; Mikkelsen et al., 2007; Mohn et al., 2008; Pan et al., 2007; Zhao et al., 2007). This alleged discrepancy may be due to the fact that the study of Bernstein and colleagues was restricted to specific regions of the genome characterized by the presence of many highly conserved non- coding elements (Bejerano et al., 2004; Nobrega et al., 2003) and being devoid of retrotransposons (Bernstein et al., 2006a; Simons et al., 2006; Tanay et al., 2007). As such, Bernstein et al. may thus have studied only a fraction of "all possible" bivalent domains. Given the predominant loss of bivalency upon differentiation, the studied highly conserved regions may harbor developmental regulators that have essential functions, particularly during early embryonic development.

Together, the studies suggest the existence of specific classes of bivalent genes that become primed at particular stages of development. Indeed, by using an in vitro differentiation protocol that enables stem cells to differentiate via lineage-committed progenitors into terminally differentiated neurons, Mohn and coworkers observed that many neuron-specific genes that become activated during terminal differentiation are bivalent targets in progenitor cells only, and not in the preceding stem cells (Mohn et al., 2008). This study also nicely shows that during lineage commitment and terminal differentiation existing bivalent domains are resolved while others are formed (Fig. 2A, part 3).

\section{CpG Island Promoters}

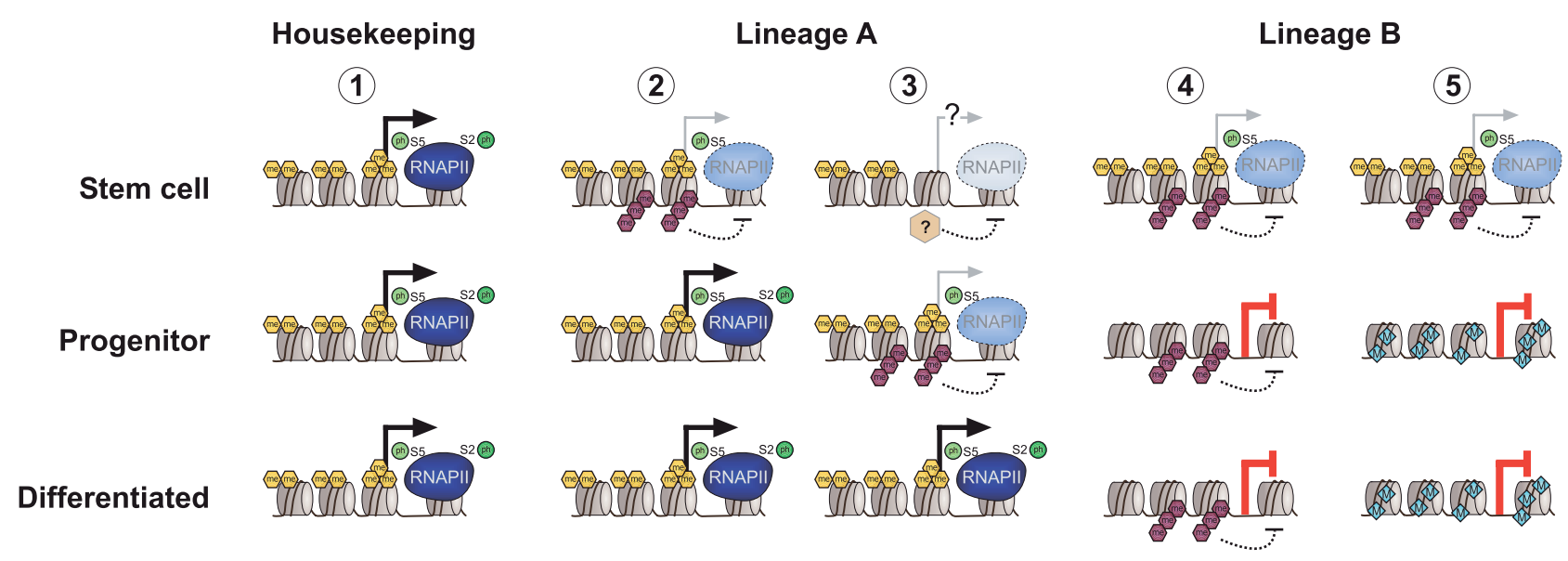

\section{Non-CpG Island Promoters}

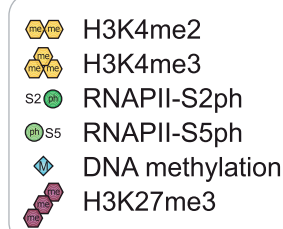

(n) $\mathrm{H} 3 \mathrm{~K} 4 \mathrm{me} 2$

H3K4me3

DNA methylation H3K27me3
Lineage A

(6)

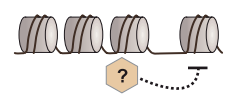

? $\cdots . . .+5$

Stem cell

Progenitor
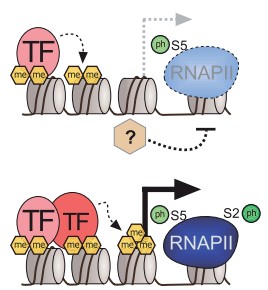

Lineage $B$

(7)

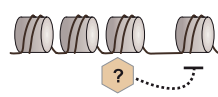

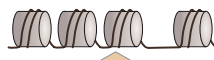
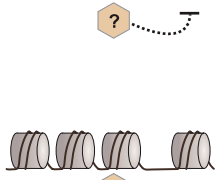

Fig. 2. Models of dynamic chromatin states at $\mathbf{C p G}$ island and non-CpG island promoters during differentiation. (Top) CpG-island promoters are H3K4 methylated by default, even when inactive (except when methylated at cytosines). Housekeeping genes are constitutively expressed, marked by H3K4me and elongating RNAPII (1). During differentiation along lineage $A$, promoters of genes functioning in lineage $A$ harbor a bivalent configuration either at the stem cell or progenitor level and become activated at the subsequent stage $(2,3)$. In contrast, genes normally expressed in lineage $B$ loose their bivalent configuration during differentiation and remain transcriptionally repressed, either by $\mathrm{H} 3 \mathrm{~K} 27 \mathrm{me} 3$ or DNA methylation $(4,5)$. It is currently unclear whether inactive promoters marked by $\mathrm{H} 3 \mathrm{~K} 4 \mathrm{me} 2 / 3$ but not $\mathrm{H} 3 \mathrm{~K} 27 \mathrm{me} 3$ (3) harbor other repressive histone modifications. (Bottom) Non-CpG island promoters
isms keeping the repressed state are currently unknown (7). A fraction of require transcription factors ("TF", 6) to be activated, whereas the mechanisms keeping the repressed state are currently unknown (7). A
genes in lineage A show low levels of H3K4me2 but not H3K4me3 at the progenitor stage, suggesting a transcriptionally poised state. 
In their initial study, Bernstein and coworkers observed a strong correlation between presence of $\mathrm{H} 3 \mathrm{~K} 4 \mathrm{me} 3$ and the density of $\mathrm{CpG}$ dinucleotides in the underlying DNA sequence (Bernstein et al., 2006a). Likewise, Weber and colleagues noticed that in mammals inactive promoters, rich in unmethylated $\mathrm{CpG}$ dinucleotides, have elevated levels of H3K4me2 (Weber et al., 2007). These studies point out that it is necessary to classify promoters according to their sequence composition in order to understand the ontogeny of bivalent domains. In mammals, RNA polymerase II (RNAPII) promoters are known to occur in at least two major forms (Saxonov et al., 2006; Weber et al., 2007); those with a normal and those with a reduced percentage of $\mathrm{CpG}$ dinucleotides. In many mammalian regulatory sequences $\mathrm{CpG}$ dinucleotides are underrepresented. This most probably reflects the inherent mutability of methylated cytosines by deamination and conversation to thymidine (Shen et al., 1994). Accordingly, CpG islands at promoters are generally devoid of cytosine methylation whereas CpG dinucleotides throughout the remaining part of the mammalian genome are methylated. Conservation of unmethylated $\mathrm{CpG}$ islands suggests that they are maintained by evolutionary constraints, e.g. as binding sites for transcription factors. CpG-rich promoters are associated with ubiquitously expressed "housekeeping" genes and with regulatory genes expressed during development. In contrast, CpG-poor promoters are generally associated with tissue-specific genes. Using a classification system that accommodates relative CpG densities (Weber et al., 2007), epigenomic studies clearly showed that bivalency is largely restricted to $\mathrm{CpG}$ island promoters, independent of the cellular differentiation status (Mikkelsen et al., 2007; Mohn et al., 2008). This strongly indicates that promoter sequence composition is a critical parameter determining the occurrence of H3K4 methylation and bivalency.

\section{Sequence determinants of mammalian promoters}

Computational analyses of extended core promoters (-100 to +100 ) showed that promoters can be sub-classified in four types on the basis of GC and AT densities upstream and downstream of the transcription start site (TSS; determined being either GCor AT-rich upstream or either GC- or AT-rich downstream of the TSS). Such classification enabled the identification of sequence elements specific to GC-rich promoter regions as well as elements specific to AT-rich promoter regions either up- or downstream of the TSS (Bajic et al., 2006). The four promoter types show marked preferences for different sets of dinucleotides at the initiating position of the TSS. They can be linked to developmental expression patterns, suggesting functional relevance of the different promoter structures for gene specific regulation. Given the presence of various DNA binding domains in H3K4 HMTs with distinct sequence specificities (see below), sub-classification of bivalent $\mathrm{CpG}$ island promoters could constitute a second layer of transcriptional regulation.

\section{H3K4: di- vs. tri-methylation does matter}

Work by Orford and colleagues shows that H3K4me2 may prime non-CpG island genes for subsequent expression during differentiation (Orford et al., 2008). The authors studied the concordance of $\mathrm{H} 3 \mathrm{~K} 4 \mathrm{me} 2$ versus $\mathrm{H} 3 \mathrm{~K} 4 \mathrm{me} 3$ on a genome wide scale during differentiation of the multipotent Sca-positive "progenitor" cells along the erythroid lineage. In both progenitor and differentiated cells, the majority of $\mathrm{H} 3 \mathrm{~K} 4 \mathrm{me} 2$ positive promoters were also positive for $\mathrm{H} 3 \mathrm{~K} 4 \mathrm{me} 3$, while a large set of genes was negative for both marks (Fig. 2B, part 7). Interestingly, a subset of genes revealed a discordant pattern of H3K4 methylation, in which H3K4me2 was present but H3K4me3 was absent (H3K4me2+/me3-). Promoters with the reciprocal set of modifications (H3K4me2-/me3+) were not detected. Upon erythroid differentiation, the percentage of $\mathrm{H} 3 \mathrm{~K} 4 \mathrm{me} 2+/ \mathrm{me} 3$ - promoters reduced by $30 \%$, with most promoters losing $\mathrm{H} 3 \mathrm{~K} 4 \mathrm{me} 2$ and some gaining H3K4me3. Transcriptome analysis indicated that whereas the majority of $\mathrm{H} 3 \mathrm{~K} 4 \mathrm{me} 2+/ \mathrm{me} 3+$ promoters were highly expressed, only $20 \%$ of $\mathrm{H} 3 \mathrm{~K} 4 \mathrm{me} 2+/ \mathrm{me} 3-$ marked genes were transcribed, and this at low levels (Orford et al., 2008). Importantly, the expression level of genes that transitioned from H3K4me2+/me3to the $\mathrm{H} 3 \mathrm{~K} 4 \mathrm{me} 2+/ \mathrm{me} 3+$ state upon differentiation was strongly upregulated, arguing that such genes have been poised for transcription at the progenitor stage (Fig. 2B, part 6).

Promoter classification indicated that particularly non-CpG island tissue-specific genes are amendable to being marked by H3K4me2 "only". Interestingly, many H3K4me2-/me3- CpG island genes in erythroid cells were among the bivalent developmental regulatory genes in ES cells (Orford et al., 2008), suggesting that bivalency at the $\mathrm{CpG}$ island genes was resolved during differentiation. It will be interesting to know whether these H3K4me2-/me3- CpG-island developmental regulatory genes are "actively" repressed in erythroid cells, e.g. by the presence of repressive histone modifications such as $\mathrm{H} 3 \mathrm{~K} 27$ me3. Similarly, it needs to be investigated whether $\mathrm{H} 3 \mathrm{~K} 4 \mathrm{me} 2+$ non-CpG island promoters are also "actively" repressed at the progenitor stage, e.g. by H3K9 methylation.

\section{Targeting mechanisms of HMTs: what we learn from distribu- tion patterns}

Epigenomic experiments revealed distinct distributions of mono, di and tri-methylated $\mathrm{H} 3 \mathrm{~K} 4$ residues around TSSs (Barski et al., 2007; Orford et al., 2008). H3K4me1/2 displays a rather broad distribution, with slight enrichments downstream of the TSS. $\mathrm{H} 3 \mathrm{~K} 4 \mathrm{me} 3$ is enriched around the TSS with a strong bias towards sequences downstream of the TSS. For all three methyl states, reduced enrichments are observed at the TSS itself, likely reflecting nucleosomal depletion at active genes. Levels of enrichment largely correlate with levels of expression. RNAPII occupancy is strongly enriched at and slightly downstream of the TSS (Barski et al., 2007). The bias of H3K4me to sequences downstream of the TSS may reflect targeting of H3K4 HMTs to actively transcribed genes through interaction with the elongating RNAPII (see below). Interestingly, differences in enrichment of H3K4me2 around the TSS for $\mathrm{H} 3 \mathrm{~K} 4 \mathrm{me} 2+/ \mathrm{me} 3+$ versus $\mathrm{H} 3 \mathrm{~K} 4 \mathrm{me} 2+/ \mathrm{me} 3-$ genes were described (Orford et al., 2008). Whereas double positive promoters were strongly enriched and showed the bimodal distribution around the TSS, levels of H3K4me2 enrichments varied across individual promoters of single positive genes. These data suggest that H3K4me2 at non CpG-island lineagespecific genes are deposited by HMTs that have been targeted by transcription factors. Consistently, consensus motifs for Runx1 and $\mathrm{Pu} .1$ are overrepresented within $\mathrm{H} 3 \mathrm{~K} 4 \mathrm{me} 2$ enriched regions of poised genes (Orford et al., 2008) (Fig. 2B, part 6).

In human ES cells, levels of H3K4me3 are lower at bivalent promoters in comparison to genes marked by H3K4me3 alone 
(Zhao et al., 2007). Furthermore, H3K27me3 and H3K4me3 largely do not co-localize at promoter sequences. Whereas $\mathrm{H} 3 \mathrm{~K} 4 \mathrm{me} 3$ is localized at and downstream of the TSS, H3K27me3 is enriched upstream and downstream of the H3K4me3 peak (Zhao et al., 2007). It is important to note that ChIP studies of Zhao and Bernstein were performed on cross-linked sonicated chromatin and not on mono-nucleosomes. It is therefore unclear whether the two antagonizing modifications can reside on the same nucleosome.

In summary, these data argue for different targeting mechanisms for H3K4 HMTs to various classes of genes, such as actively transcribed $\mathrm{CpG}$-island house keeping genes, repressed CpG-island bivalent genes, actively transcribed non-CpG-island tissue-specific genes and poised H3K4me2+/me3- non-CpGisland lineage/tissue-specific genes.

\section{Stalling RNAPII}

As for H3K4 methylation, an epigenomic study on RNAPII and histone modification occupancy hints to a mechanistic link between type of target genes and mode of transcriptional repression. Guenther and colleagues (Guenther et al., 2007) profiled various histone modifications associated with the initiating (RNAPIIS5P; H3K9 and H3K14 acetylation, H3K4me3) and elongating RNA polymerase II (RNAPII-S2P; H3K36me3 and H3K79me2). They found that about three quarters of protein-coding genes have promoter proximal nucleosomes enriched for $\mathrm{H} 3 \mathrm{~K} 4 \mathrm{me} 3$ and $\mathrm{H} 3$ acetylation, whereas the initiating form of RNAPII was present at half of the genes, possibly relating to differences in ChIP efficiency. Moreover, activating marks were not only present at active but also at more than half of the inactive promoters, though being less enriched in the later situation. A large fraction of inactive genes also contained the initiating form of RNAPII, yet at strongly reduced levels. It remains to be determined whether at some of the H3K4me marked promoters lacking RNAPII the modification is targeted independent of the polymerase. H3K36me3 and H3K79me2 modifications were only enriched along the coding part of expressed genes, consistent with their deposition in conjunction with the elongating form of RNAPII. This work thus shows that a substantial number of genes is transcriptionally initiated but not elongated (Guenther et al., 2007). Furthermore, developmental regulatory genes are enriched among these genes, as has been observed for H3K27me3 and H3K4me enriched promoters, suggesting that Polycomb may "arrest" RNAP after initiation but before elongation. This is consistent with work by Pombo and colleagues, revealing a regulatory role for PRC1 in transcriptional elongation (Stock et al., 2007).

To be able to connect our current knowledge on promoter structure, sequence and presence of transcription factor binding sites (TFBS) to patterns of histone modifications and transcriptional states, we will review the composition, modes of action and possible ways of targeting of HMTs and HDMs. Subsequently, we propose a working model for Polycomb-mediated repression, integrating promoter sequence as well as the agonistic and antagonistic actions of demethylases and H3K4 HMTs.

\section{H3K4 histone methyltransferases}

The mammalian genome harbors over 10 different H3K4 HMTs. Six of them (Set1a, Set1b, Mixed lineage leukemia 1 to 4
(MIl1-4)) are close homologues of the S. cerevisiae and S. pombe Set1 proteins that function in complexes called COMPASS (Lee et al., 2007a). Other H3K4 HMTs include Ash1L, Set7/9, Smyd1, Smyd3, and Prdm9/Meisetz (see Fig. 1). Set1 and Mll function in multi-protein complexes that share three core components (WDR5, RbBP5, and Ash2L). In vitro reconstitution experiments show that both WD-40 repeat containing proteins RbBP5 and WDR5 are required for stable association with the C-terminal part of Mll1 (Dou et al., 2006) whereas Ash2L interacts with RbBP5 only. Structural studies revealed that WDR5 plays a scaffolding role and presents the H3K4 side chain for methylation to MII/Set1 (Couture et al., 2006; Han et al., 2006; Ruthenburg et al., 2006; Schuetz et al., 2006). siRNA-mediated knockdown of either RbBP5 or WDR5 leads to a major reduction of global H3K4me2 and H3K4me3 (Dou et al., 2006), whereas depletion of Ash2L only reduced H3K4me3 (Dou et al., 2006; Steward et al., 2006). These results strongly suggest that the SET1 family members jointly account for the majority of $\mathrm{H} 3 \mathrm{~K} 4$ methylation in mammalian cells. For this later reason, we limit our in-depth review to Set1 and MII proteins.

\section{hSet1a and hSet1b HMTs}

The human hSET1a and hSET1b complexes contain two additional proteins (WDR82 and CFP1) that are also present in the orthologous yeast complexes (Lee and Skalnik, 2008; Lee et al., 2007a), suggesting that these enzymes represent the true functional yeast Set1 homologues. Consistently, several house keeping genes are regulated by hSet1A, including GAPDH (Lee and Skalnik, 2008). Both enzymes are ubiquitously expressed but display different sub-nuclear localization patterns, arguing for target specificity (Lee et al., 2007a).

WDR82 can simultaneously interact with the initiating form of RNAPII and either hSET1a or hSET1b. As such, it can facilitate targeting of the HMTs to transcriptional start sites and can direct local accumulation of H3K4me2/3 (Lee and Skalnik, 2008), thereby sustaining ongoing transcription. The CxxC Finger Protein 1 (CFP1; previously called CpG-binding Protein or CGBP) may target hSet1a/b complexes via its CxxC DNA methyltransferase homology domain to non-methylated CpG-island promoters (Voo et al., 2000). This domain is present in several proteins such as DNA methyltransferase 1, MII1/2 and MBD1. CFP1 homologues in organisms lacking $\mathrm{CpG}$ methylation also lack the CxxC DNA methyltransferase domain, suggesting evolutionary selection. Surprisingly, H3K4me2/3 levels are slightly up-regulated in CFP1 deficient ES cells (Lee and Skalnik, 2005). Taken together, these data suggest that CFP1 may facilitate targeting of the Compass HMT complexes to selected CpG-island target genes. Given the peri-implantation embryonic lethality of CFP1 deficient mice (Carlone and Skalnik, 2001), prior to the death of MIl1 or MII2 deficient animals (Glaser et al., 2006; Yu et al., 1995), CFP1 may have a crucial function in transcriptional control of many genes.

\section{Mixed lineage-leukemia HMTs}

Five mammalian MII proteins are members of the Trithorax group of proteins (Fig. 1). The functional importance of these enzymes was first identified in Drosophila, where the Trithorax HMT regulates maintenance of Hox gene expression by counteracting the repressive Polycomb action (reviewed in (Ringrose and Paro, 2004)). MIl1-4 are part of multiprotein complexes catalyzing 
the transfer of mono-, di- and trimethyl groups to H3K4.

\section{MII1}

Mll1 is essential for embryonic development and homeotic gene regulation. Targeted deletion of MIl1 leads to embryonic lethality at embryonic day E10.5 of development (Yu et al., 1995). MIl1 targets are appropriately activated in $\mathrm{M} / 11^{-1-}$ animals, yet expression fails to be maintained (Yu et al., 1998), resembling the situation in the fly where Trx proteins are required for transcriptional memory. MII1 heterozygous animals are haploinsufficient since they display growth retardation and misregulated Hox expression (Yu et al., 1995). Chromosomal translocations fusing the N-terminal domain of Mll to various erythroid DNA binding factors and chromatin modifying enzymes result almost always in acute leukemia (Hess, 2004), further corroborating the transcriptional potency of Mll proteins.

MII1 is proteolytically cleaved by an evolutionary conserved Taspase (Hsieh et al., 2003a), and cleavage is required for $\mathrm{H} 3 \mathrm{~K} 4$ methylation and regulation of Hox gene expression (Hsieh et al., 2003a; Hsieh et al., 2003b; Yagi et al., 1998). Both fragments, MIIN and $\mathrm{MIC}$, remain associated by interaction of domains located near the cleavage site. $\mathrm{MII}^{\mathrm{C}}$ harbors the catalytically active SET domain mediating high levels of H3K4me when present in the core complex (Dou et al., 2006). The MIIC fragment recruits histone acetyltransferases CBP/p300 and MOF (Dou et al., 2005; Ernst et al., 2001), suggesting a main role of Mll1 in transcriptional activation. Components of TFIID, of chromatin remodelers Swi/ Snf and hSNF2h, but also of NuRD and Sin3A complexes are reported to interact with MII1 (Nakamura et al., 2002), pointing to widespread functions for MII1 in transcriptional regulation.

Different mechanisms facilitate MII1 recruitment to target genes. MII1 has been shown to interact with the initiating form of RNAPII (Milne et al., 2005a), and Mll1 is present at 93\% of promoters marked by RNAPII (Guenther et al., 2005). This co-occupancy of MII1 and RNAPII suggests a global role of MII1 in transcriptional activation. However, the study by Milne et al. demonstrated Mll1 association only to selected target genes (e.g. Hox9a) and along gene bodies. Although the reason for the discrepancy between the two studies is unclear, the direct connection of MII1 to RNAPII is undoubted, possibly providing a positive feedback once targeting via sequence specific factors has taken place. The $\mathrm{N}$-terminal fragment of Mll1 contains sequence motifs and domains implicated in chromatin binding (such as AT hooks, a CxxC DNA methyltransferase homology domain, PHD domains and a Bromo domain). Given the sequence conservation of the PHD domains with those present in various ING proteins (reviewed in (Ruthenburg et al., 2007)) and human BPTF (Li et al., 2006) which are known to bind to methylated $\mathrm{H} 3 \mathrm{~K} 4$, Mll1 may have the intrinsic capacity to bind to its own enzymatic product. It is tempting to speculate that the Bromo-domain confers binding to acetylated lysines on histones, providing means for Mll1 retention at actively transcribed genes. Like CFP1, MIl1 and MIl2 have a CxxC DNA methyltransferase homology domain (Ayton et al., 2004; Glaser et al., 2006). In Mll1, this domain was shown to mediate binding to non-methylated CpG-rich DNA in vitro (Allen et al., 2006; Ayton et al., 2004; Birke et al., 2002) and transcriptional activation in vivo (Ayton et al., 2004). Oncogenic Mll1-fusions require the CxxC domain for myeloid transformation (Ayton et al., 2004). Intriguingly, MIl1 is required to prevent DNA methylation at specific CpG dinucleotides in the upstream promoter of the Hoxa9gene (Erfurth et al., 2008), whereby the CxxC domain shows increased binding to sequences that display MII1-dependent protection against $\mathrm{CpG}$ methylation. These data clearly assign a function to the CxxC domain in selectively protecting CpG islands against DNA methylation. It may, however, also allow discrimination between nonmethylated $\mathrm{CpG}$ island promoters and CpG-poor promoters methylated at $\mathrm{CpG}$ dinucleotides irrespective of their expression status (Weber et al., 2007). Ansari and colleagues reported that CFP1 interacts not only with hSet1 but also with MIl1 and MII2, thereby increasing the potential of MII1 and MII2 to interact with unmethylated CpG island promoters (Ansari et al., 2008). Although not required for myeloid transformation in oncogenic Mll1fusions (Ayton et al., 2004) the three AT hooks present in Mll1 may direct the protein to AT-rich sequences. Given the existence of hybrid promoters that are GC-rich upstream and AT-rich downstream of the TSS and vice-versa (Bajic et al., 2006), it will be interesting to relate binding profiles of MII1 to underlying promoter sequences of target genes. MII1 also interacts with a number of transcription factors important for cell cycle progression (see below). Finally, one study reported that part of $\mathrm{MIIN}$, including the CxxC domain, is able to interact with components of the PRC1 complex, with the histone deacetylase Hdac1 and the corepressor protein CtBP (Xia et al., 2003). It will be important to determine whether particularly such interactions are relevant for the formation of the bivalent state.

\section{MII2 (also called Trx2)}

MII1 and MII2 are closely related proteins that originated from gene duplication. Although having similar protein architectures, MII2 lacks the Bromo domain. MII2 is also proteolytically cleaved and resides in similar complexes as MII1. MII2 gene deficient animals die at E11.5 and display retarded growth and development and increased apoptosis (Glaser et al., 2006). Embryonic lethality of mice either deficient for MII1 or MII2 indicates that these genes serve non-redundant functions (Glaser et al., 2006). Transcription of MII2 target genes is correctly established, yet maintenance of expression was affected for a selected subset (Glaser et al., 2006). MII2-- ES cells are viable and retain pluripotency but display cell proliferation defects due to increased levels of apoptosis (Lubitz et al., 2007). MIl2 interacts with several different transcription factors, possibly providing target specificity. For example, MII2 binds to ligand-activated ER $\alpha$ through two LXXLL motifs, thereby being targeted to Estrogen responsive genes (Mo et al., 2006). Also, the hematopoietic transcription factor NF-E2 recruits the MII2 complex (Demers et al., 2007). Interestingly, spreading of MII2, but not the associated complex member Ash2 is observed across the beta-globin locus, suggesting a mechanism by which an activator influences transcription and H3K4me3 at a distance (Demers et al., 2007).

\section{MII3 and MII4}

Information about MII3 and MII4 members is rather scarce. However, complexes with either protein have been demonstrated to mono-, di- and tri-methylate H3K4 (Cho et al., 2007; Patel et al., 2007). Structurally, both proteins are even larger than Mll1 and MII2. Instead of having multiple AT-hooks and CxxC-domains, both proteins harbor an HMG box, known to penetrate into the minor groove of DNA and sharply bending it (Hock et al., 2007). 
The transcription factor Pax2 targets MII3 to chromatin via an interaction with the bridging protein PTIP (Patel et al., 2007).

\section{Polycomb group proteins}

\section{Polycomb group proteins: complex compositions}

In mammals, PcG proteins are classified into two groups of multimeric protein complexes termed Polycomb Repressive Complexes (PRCs). The PRC2 complex consists of Enhancer of zeste 2 (Ezh2), Suppressor of zeste 12 (Suz12), Embryonic ectoderm development (Eed) and the histone binding proteins RbAp46/ RbAp48. While Ezh2 confers HMT activity, Suz12 is required to stabilize the complex and to recruit RbAp48 (Pasini et al., 2004). In mammals, different isoforms of Eed direct the Ezh2 HMT activity towards H1K26 (Eed2), H3K27me2/3 (Eed3) and SirT1 (Eed4) (Kuzmichev et al., 2004; Kuzmichev et al., 2005), though the in vivo functional significance of these specificities remains to be determined. Like Ezh2, its close homolog Ezh1 forms a PRC2like complex together with Eed and Suz12. This complex also mediates H3K27me2/3, though to a lesser extent than the canonical Ezh2/PRC2 complex (Shen et al., 2008; Margueron et al., 2008). Knockdown experiments in Ezh2 deficient ES cells show that Ezh1 is required for H3K27me1 (Shen et al., 2008). Since Eed is required for all three methylation states of H3K27 Montgomery et al., 2005; Chamberlain et al., 2008), Ezh2 may mediate H3K27me1 as well.

For PRC1, duplication of many PcG genes in mammals allows the assembly of various, functionally distinct PRC1 complexes depending on cell type and developmental stage (Levine et al., 2002; Otte and Kwaks, 2003; Whitcomb et al., 2007). The five Cbx proteins (Cbx2, Cbx4, Cbx6, Cbx7 and $\mathrm{Cbx} 8)$, homologs of the fly Polycomb protein, have well conserved chromodomains (Whitcomb et al., 2007) that display distinct in vitro binding specificities towards H3K27me3 and H3K9me3 (Bernstein et al., 2006b). In addition, the Cbx proteins contain a conserved Pc-box at the C-terminus, a 15 amino acid motif necessary for interaction with Ring1a and Rnf2 (Garcia et al., 1999; Whitcomb et al., 2007). Polyhomeotic 1 (Phc1) has a FCS finger at its C-terminus which binds to RNA and regulates sub-nuclear localization when tested in C. elegans (Zhang et al., 2004). The mammalian Ring1a and Rnf2 proteins contain a RING domain that mediates E3 ubiquitinligase activity, resulting in mono-ubiquitination of histone $\mathrm{H} 2 \mathrm{~A}$ at K119 (H2AK119ub1) (Cao et al., 2005; de Napoles et al., 2004; Wang et al., 2004a). Additional RING domains are present in Bmi1 and Mel18 (Rnf110). These proteins direct the catalytic activity of Ring1a/Rnf2 towards H2A lysine 119 (Buchwald et al., 2006; Elderkin et al., 2007).

\section{Polycomb group proteins: mechanisms of repression}

H3K27me3 and H2AK119ub1 are thought to cooperatively mediate gene silencing, and $\mathrm{H} 2 \mathrm{AK} 119 \mathrm{ub} 1$ has been proposed to function downstream of H3K27me3 (Cao et al., 2005; Wang et al., 2004b). In vitro, PRC1 complexes inhibit chromatin remodeling and induce compaction of nucleosome arrays, which requires the presence of nucleosomes but not of histone tails (King et al., 2002; Shao et al., 1999). There is, however, no strong evidence supporting PcG-induced chromatin compaction in vivo (Schwartz and Pirrotta, 2007). Instead, binding of PRC1 proteins in vivo is highly dynamic (Ficz et al., 2005). Live imaging studies suggest that mobility of PRC1 proteins increases upon induction of ES cell differentiation but decreases again as differentiation progresses (Ren et al., 2008). Our understanding of how PcG proteins mediate their repressive function in vivo is still very limited. Access of the transcription machinery itself does not seem to be blocked; rather the activity of the transcriptional machinery at the promoter is affected by PcG proteins, preventing transcription initiation (Dellino et al., 2004). A recent study analyzing bivalent genes in ES cells supports this idea by showing that RNAPII assembles at the promoters of these genes but is held in check by the PRC1 complex and/or PRC1-mediated H2AK119ub1 (Stock et al., 2007). Stock and co-workers reported that the initiating form of RNAPII phosphorylated at Serine 5 of the CTD repeat (S5P) localizes to promoters and coding regions of bivalent genes as it is the case at actively expressed genes. Bivalent genes, however, lack the elongating form of RNAPII (S2P). Instead, they are marked by the core PRC1 protein Rnf2 and by H2AK119ub1. Interestingly, for some bivalent genes 5'-unspliced and spliced transcripts were observed, that were sensitive to the RNAPII inhibitor $\alpha$-amanitin. These data suggest that although RNAPII levels at bivalent genes are comparable to productively expressed genes, either elongation is inefficient or transcripts are rapidly degraded.

Expression of bivalent genes was found to be rapidly increased upon loss of Rnf2 occupancy in an ES line deficient for Ring1a and conditionally deficient for Rnf2, coupled with no obvious changes in levels of elongating RNAPII (Stock et al., 2007). The data suggest that PRC1 "holds" RNAPII in a maturation state incompatible with efficient transcription. The reason why RNAPII-S2P levels remain low is unclear. Interestingly, Zhou et al. (2008) observed that the histone H2A E3 ubiquitin ligase 2A-HUB (and not Rnf2 or Ring1a), is selectively required for deposition of H2AK119ub1 and subsequent repression of target genes after recruitment by the co-repressor N-CoR (Zhou et al., 2008). They show that H2AK119ub1 prevents recruitment of FACT and nucleosome remodeling at promoters and coding regions, thus blocking RNAPII at the early stage of elongation. Consistently, knock down of 2A-HUB results in decrease of H2AK119ub1 and in increase of RNAPII-S2P along the coding part of target genes (Zhou et al., 2008). Removing ubiquitin from H2A may increase interaction between $\mathrm{H} 2 \mathrm{~A}$ and FACT, thereby promoting transcriptional elongation upon gene activation (see also below). A similar mechanism may act at PcG repressed genes.

Recently, the Drosophila PRC1 components RING and PSC were identified to be part of an additional complex, called RAF, that also contains dKDM2, a H3K36me2 specific demethylase, and dRAF2, a MYND zinc finger containing protein (Lagarou et al., 2008). dKDM2 enables efficient mono ubiquitination of $\mathrm{H} 2 \mathrm{~A}$ by RING/PSC in a catalytically independent manner. This suggests that dKDM2 may fulfill a structural function for RING/PSC or facilitates interaction of RING/PSC with chromatin. Nevertheless, since purified mononucleosomes harbored either H3K36me2 or mono ubiquitinated $\mathrm{H} 2 \mathrm{~A}$ but not both modifications, dKDM2 mediated H3K36me2 demethylation likely acts upstream of the RING/PSC ubiquitination reaction. Finally, dKDM2 cooperates with $P C$ in repressing homeotic genes while it counteracts homeotic gene activation by the TrxG histone methyltransferases TRX and ASH1. Since H3K36me2 is a mark involved in transcriptional elongation, this study further supports the notion that APRC1 and 
dRAF mediated silencing acts via blocking transcriptional elongation.

\section{Targeting of polycomb group proteins}

In Drosophila, a number of DNA binding proteins have been identified that recruit PcG complexes to Polycomb response elements (PRE), sequences that control the transcriptional status of their associated promoters at a distance. So far, no PREs have been identified in mammals, despite the availability of large-scale ChIP data sets for chromatin modifications and for different PRC2 and PRC1 members. Among the many Drosophila PRE binding proteins, only $\mathrm{PHO}$ and $\mathrm{PHO}-\mathrm{L}$ are conserved in mammals, referred to as YY1 (Brown et al., 2003; Brown et al., 1998). In mouse mid-gestation embryos, $Y Y 1$ is engaged with distinct PRC1 and PRC2 complexes. Biochemical studies indicate that PRC2-mediated H3K27me3 can provide a docking site for the PRC1 complex which recognizes methyl-lysine residues via the chromodomain of Polycomb (Fischle et al., 2003; Min et al., 2003). Consistently, PRC2 function is required for binding of PRC1 at several genes (Boyer et al., 2006). Moreover, in one-cell embryos lacking maternal and zygotic expression of Ezh2, the level of binding of PRC1 components to "euchromatin" directly correlates with levels of H3K27me2 and H3K27me3 (Puschendorf et al., 2008). In contrast, de novo acquisition and maintenance of H3K27me3 was unaffected in embryos lacking the PRC1 complex. These data indicate a unidirectional relation, in which global chromatin association of PRC1 depends on PRC2-mediated $\mathrm{H} 3 \mathrm{~K} 27 \mathrm{me} 2 / 3$ but not vice versa. It is important to note that at this stage of development, the two parental genomes are largely transcriptionally inactive. At subsequent stages of pre-implantation development, however, "global" association of PRC1 to chromatin is not affected by Ezh2 deficiency (Terranova et al., 2008). Similarly, targeting of PRC1 to pericentric heterochromatin in early embryos or to the inactivated $X$ during $E S$ differentiation does not require H3K27me3. This clearly indicates that depending on the cellular condition multiple mechanisms contribute to targeting of PRC1.

Loss of function studies in ES cells indicate a tight correlation between PRC1 occupancy, gene repression and protection against differentiation (Endoh et al., 2008). Although global levels of PRC2 components and H3K27me3 remain constant after loss of Ring1a and Rnf2, Eed occupancy was rapidly reduced at specific target genes suggesting feedback between PRC1 and PRC2 targeting. H3K27me3 levels got reduced less rapidly, possibly reflecting differential antibody avidity or lack of H3K27me3 demethylase activity. Whether presence of H3K27me3 itself is also involved in maintaining PRC2 at target genes is currently unclear.

Genome-wide studies revealed a significant overlap between genes bound by the pluripotency transcription factors OCT4, SOX2 and NANOG and by PcG proteins (Lee et al., 2006b). Consistently, loss of function studies revealed a significant overlap in genes de-repressed in ES cells lacking Oct3/4 or Ring1a/ Rnf2 or Eed but not in Dnmt1 deficient cells, arguing for common targets between PcG proteins and Oct4 (Endoh et al., 2008). ChIP studies in mutant cells confirmed that Oct4 is required for targeting of PRC1 and PRC2 but not vice versa (Endoh et al., 2008). Similarly, an independent study showed that a fraction of genes bound by Oct4 are de-repressed upon loss of Rnf2. A direct association has so far not been demonstrated (van der Stoop et al., 2008). Importantly, the great majority of genes bound and transcriptionally repressed by Rnf2 is controlled by CpG-island promoters. Furthermore, three quarters of these $\mathrm{CpG}$ island genes have the bivalent configuration in wild-type ES cells, belong to the class of developmental regulators and are predominantly de-repressed in absence of Rnf2 (van der Stoop et al., 2008). Thus, PRC1 seems to predominantly repress bivalent genes in ES cells. The remaining quarter of CpG-island genes bound by Rnf2 were marked by H3K4me3 but not H3K27me3 (van der Stoop et al., 2008) suggesting PRC2-independent recruitment of PRC1. These later genes were not substantially repressed in wild-type cells, although loss of Rnf2 resulted in increased expression in two-thirds of these genes (van der Stoop et al., 2008). These data support the idea that PRC2 and PRC1 cooperate for efficient repression of $\mathrm{CpG}$ island genes, marked by H3K4 methylation. It will be important to compare the level of H2AK119ub1 at the two distinct classes of Rnf2-bound genes. "Genome wide" comparison of H3K27me3, Ezh2, Suz12, and Rnf2 occupancies revealed the existence of two classes of bivalent promoters (Ku et al., 2008). Only less than half of PRC2 positive promoters were positive for Rnf2. Interestingly, PRC2/ Rnf2 double positive promoters more efficiently retained H3K27me3 upon differentiation and were more enriched in developmental regulatory gene functions. These data argue for a role of PRC1 in long term memory of the repressed state during development.

Several studies suggest that non-coding RNAs may be involved in the recruitment of PcG complexes. For example, Rinn and colleagues identified a $2.2 \mathrm{~kb}$ non-coding RNA in the human HOXC cluster termed HOTAIR that interacts with PRC2 components and represses transcription of the HOXD cluster in trans (Rinn et al., 2007). Likewise, the Xist transcript is required to target PRC2 and H3K27me3 to the $X$ chromosome during $X$ inactivation (Zhao et al., 2008). The mechanism of PRC1 targeting is unknown (Leeb and Wutz, 2007; Schoeftner et al., 2006). A similar mechanism may function at certain imprinted clusters characterized by expression of a long non-coding RNA, required for silencing and H3K27me3 deposition in cis (Lewis et al., 2004; Mager et al., 2003; Umlauf et al., 2004; Terranova et al., 2008). Consistently, PRC2 was shown to interact with the noncoding ncRNA Kcnq1 ot 1, that is required for imprinted repression (Pandey et al., 2008). In summary, multiple non-mutually exclusive mechanisms (e.g. transcription factors, non-coding RNAs, and DNA/ RNA-binding domains within PcG components) can contribute to the binding of PRC2 and PRC1 complexes to chromatin. PRC2mediated H3K27me3 may serve to recruit or stabilize binding of PRC1 depending on the local chromatin configuration and/or transcriptional and developmental status of the cell.

\section{Polycomb- and Trithorax-mediated chromatin marks are reversible}

\section{H3K27me3 HDMs}

The human genome encodes 27 proteins with JmjC domains, of which 15 have been shown to demethylate histone lysines (Agger et al., 2008). Two of these histone demethylases (HDMs), UTX and JMJD3, are specific for H3K27me (Agger et al., 2007; De Santa et al., 2007; Lan et al., 2007; Lee et al., 2007c). In vitro, both 
enzymes catalyze the transition from H3K27me3 and H3K27me2 to H3K27me1 on bulk histones by oxidative demethylation (Cloos et al., 2008) (Fig. 1).

UTX is localized on the $X$ chromosome, but escapes $X$ inactivation in females. Inhibition of UTX results in a global increase in H3K27me3, suggesting that histone demethylation is continuously required to maintain precise levels of methylation (Agger et al., 2007). Consistent with the loss of H3K27me3 observed at HOX genes during differentiation, UTX is recruited to the promoters of several HOX genes, coinciding with the disappearance of H3K27me3 and decreased PRC2 occupancy (Agger et al., 2007; Lan et al., 2007). Conversely, knock-down of UTX leads to increased $\mathrm{H} 3 \mathrm{~K} 27 \mathrm{me} 3$, enhanced binding of $\mathrm{PRC} 1$ proteins and increased H2AK119ub1 at HOX genes (Lan et al., 2007; Lee et al., 2007c). In Zebrafish, inhibition of Utx1 leads to decreased expression of Hox genes and improper development of the posterior trunk (Lan et al., 2007). These defects were partially rescued by wild-type but not catalytically inactive human UTX, indicating that demethylase activity is evolutionarily conserved and required for proper posterior patterning. Overexpression of JMJD3, but not UTX, results in global H3K27 demethylation in vivo (Agger et al., 2007). Ubiquitous expression of Utx versus restricted expression of Jmjd3 (Lan et al., 2007; de Santa et al., 2007) points to different functions during development. Interest-

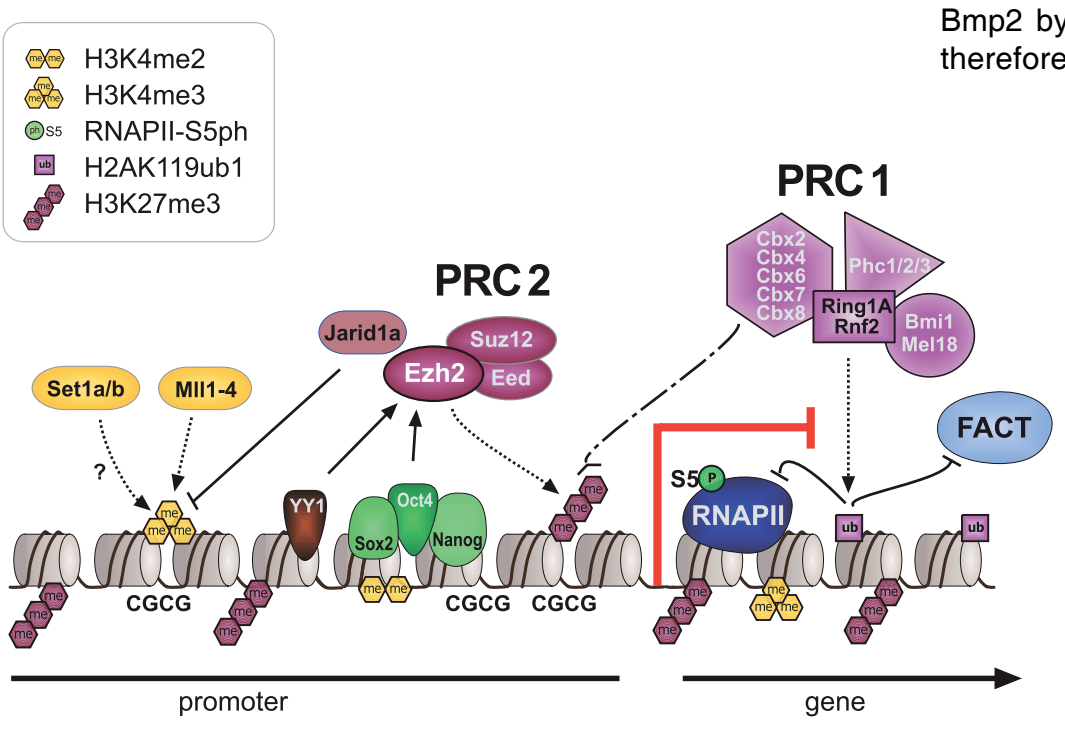

Fig. 3. Transcriptional repression at $\mathbf{C p G}$ island bivalent promoters. In mammalian cells, promoters of developmental regulators are marked by both "active" H3K4me2/ 3 and "repressive" H3K27me3, and are therefore termed "bivalent". Bivalency correlates strongly with high GC density, as present in CpG island promoters. Despite the presence of $H 3 K 4 m e 2 / 3$, which is likely mediated by the MII and/or Set1a/b enzymes, bivalent genes are largely repressed by Polycomb mediated mechanisms. In mammals, targeting of Polycomb complexes is still poorly understood. Of the DNA binding factors recruiting Polycomb in flies, only YY1 is conserved. However, the pluripotency transcription factors Sox2, Oct4 and Nanog co-occupy a large fraction of Polycomb-bound genes, and Oct4 was recently shown to be required for targeting of $P R C 2$ and $P R C 1$ to repressed Oct4 target genes. PRC2-mediated H3K27me3 provides a binding site for PRC1, which in turn mediates monoubiquitination of H2AK119. Moreover, Jarid1a targeted by PRC2 downregulates H3K4me2/3 levels. The initiating form of RNA polymerase II (RNAP-S5P) is present at bivalent genes but is arrested before elongation, presumably by H2AK119ub1 inhibiting recruitment of the remodeling complex FACT. ingly, Jmjd3 expression is highly induced by inflammatory stimuli in macrophages, suggesting that this HDM may contribute to (De Santa et al., 2007; Lan et al., 2007). neurons (Jepsen et al., 2007).

Little is known about targeting mechanisms of Utx and Jmjd3. $X$ co-localizes with the elongating form of RNAPI ( are found in complexes with HMTs that act antagonistic to the marks removed by the respective HDM (Agger et al., 2008; Cho components of the MII/Set1 complexes (De Santa et al., 2007; Lee et al., 2007c). MII2, but not MIl1, was reported to co-immunowith Jmjd3 (De Santa et al., 2007), whereas UTX (h) 3 HDMs and H3K4 HMTs. In light of this, it interesting inper upon activation of these cells by inflammatory signals (De Santa et al., 2007). Incorporation of the de novo produced Jmjd3 HDM into the MII2 complex, possibly already pre-existing at the bivalent promoter, may therefore enable rapid and strong de-repression of mp2 by removing the repressive H3K27me3. Bivalency may constitute an efficient mechanism enabling promoters to rapidly respond to changes in developmental as well as environmental cues.

\section{H3K4 HDMs}

Vice versa, H3K4 HDMs are part of repressive complexes. For example, Shiekhattar and colleagues reported the interaction between Jarid1d/Smcy and Ring6a/MBLR, a protein with sequence homology to the PRC1 components Bmi1 and Mel18 (Lee et al., 2007b). Association of Ring6a to Jarid1d stimulated its in vitro H3K4 HDM activity. Moreover, knock-down of either Jarid1d or Ring6a increased Engrailed2 expression and enhanced levels of $\mathrm{H} 3 \mathrm{~K} 4 \mathrm{me} 2 / 3$ at the promoter, arguing for functional interdependency for transcriptional repression. Consistently, higher levels of components of the basal transcription machinery, RNAPII and BPTF, were observed at the Engrailed2 promoter (Wysocka et al., 2006). Taken together, the Jarid1d-Ring6a complex constitutes a novel transcriptional co-repressor entity that is distinct from the E2F6 repressive complex containing several RING proteins and G9a (Ogawa et al., 2002) and also distinct from the canonical PRC1 complex.

Interestingly, the HDM Jarid1a/Rbp2 co-purifies with the PRC2 complex (Agger et al., 2008). Jarid1a and PRC2 components co-localize to promoter regions of bivalent target genes in ES cells. Importantly, this localization is largely abrogated in Suz12 deficient cells (Pasini et al., 2008) arguing that PRC2 is a major determinant for Jarid1a targeting. All members of the Jarid1a family harbor an Arid (also called Bright) domain that potentially binds to DNA. In Jarid1b/Plu.1, 
the Arid domain has a preferential affinity for GC-rich motifs (Scibetta et al., 2007), suggesting that this domain can confer additional binding capacity to CpG-rich bivalent target genes. Knock-down experiments verified that Jarid1a is required for repression of bivalent genes by lowering H3K4me3 levels. Interestingly, H3K27me3 levels remained constant upon Jarid1a knock-down, despite an increase in expression and H3K4me3 levels (Pasini et al., 2008). Although it is unclear whether knockdown of Jarid1a results in maximal de-repression, the data argue that the actual ratio between repressive and active histone methylation marks is (directly or indirectly) an important determinant for efficient repression versus productive transcription.

\section{Repressed}

A

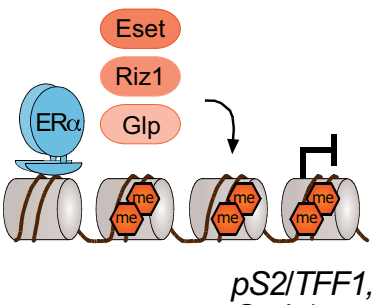

Greb1

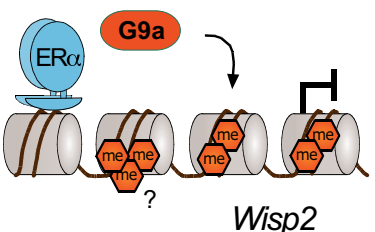

B

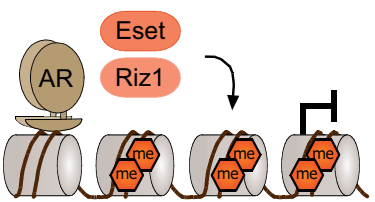

Psa, Klk2,

Nkx3.1, Tmprss2

C

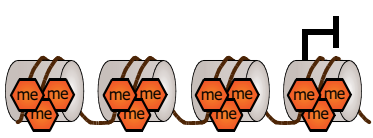

Psa, $\mathrm{Pb}$,

KIk2, MMTV

D
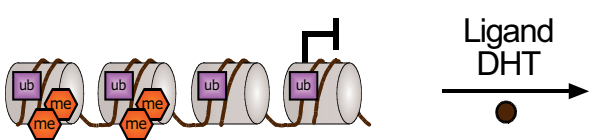

$$
\text { 2 }
$$
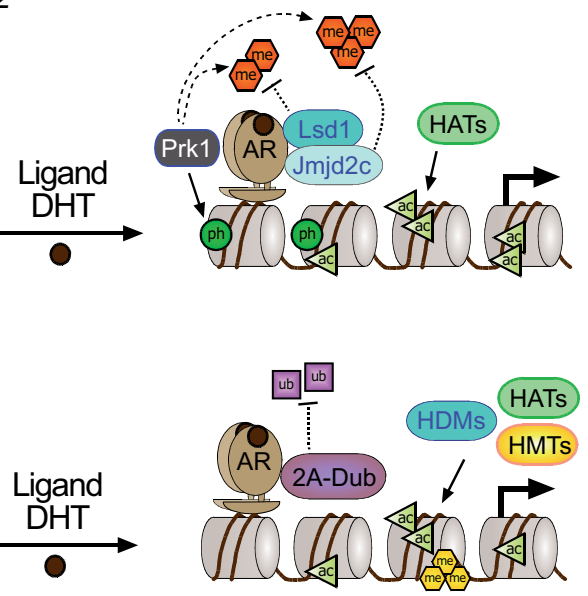

Psa, Nkx3.1, 2a-Dub
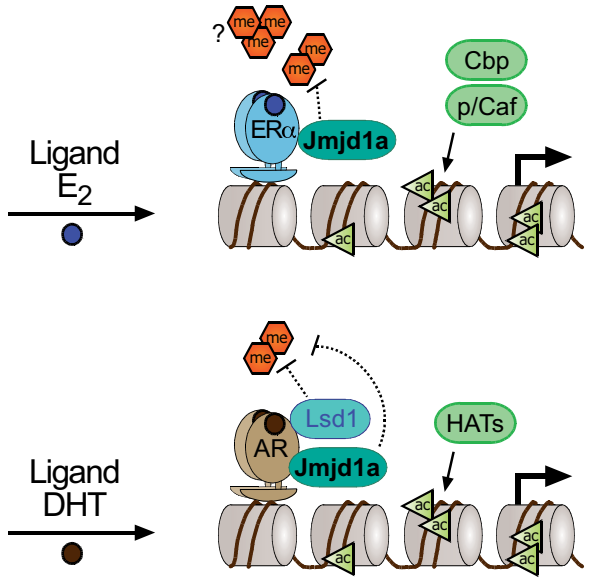

\section{Activated}

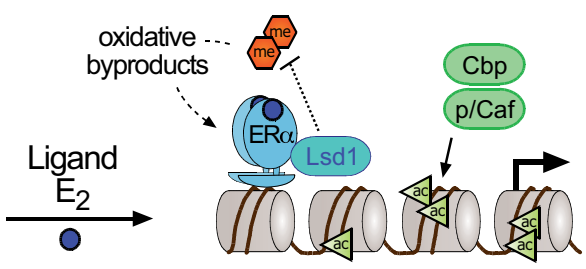

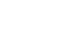

\section{Histone deubiquitination}

In addition to HDMs, recently a number of mammalian de-ubiquitinating (DUB) enzymes have been characterized including the ubiquitinspecific proteases USP3, USP16 (Ubp-M), USP21 and 2A-DUB (Joo et al., 2007; Nakagawa et al., 2008; Nicassio et al., 2007; Zhu et al., 2007). USP3 de-ubiquitinates both $\mathrm{H} 2 \mathrm{~A}$ and $\mathrm{H} 2 \mathrm{~B}$, is required for $\mathrm{S}$ phase progression and is involved in the response to DNA double strand breaks. In contrast, USP21 is specific for $\mathrm{H} 2 \mathrm{~A}$ deubiquitination (Nicassio et al., 2007). 2ADUB regulates transcription by coordinating histone acetylation and deubiquitination, and by destabilizing association of linker histone $\mathrm{H} 1$ with nucleosomes. It interacts with the histone acetyltransferase P/CAF and several different transcription factors, suggesting target specificity (Zhu et al., 2007). The de-ubiquitinating enzyme USP16 might be linked to TrxG/PcGmediated regulation, as blocking its function leads to decreased HoxD11 expression in Hela

Fig. 4. Nuclear hormone receptors and histone modification pathways. (A) The unliganded Estrogen Receptor (ER) recruits H3K9 HMTs Eset, Glp or Riz1 to target genes that need to be maintained in a repressed state. Upon ligand binding, the HDM Lsd1 clears promoter associated H3K9me2. An alternative ER pathway at distinct target genes involves recruitment of G9a and Jmjd1a. It is not known, how eventual G9a-mediated H3K9me3 is resolved in this scenario (Metivier et al., 2003; Garcia Bassetts et al., 2007; Perillo et al., 2008). (B) Unliganded Androgen Receptor $(A R)$ follows a similar strategy as the ER in the establishment of the preventive "Gatekeeper" situation. However, Glp is not recruited for maintenance of repression, and for the reversal of the silenced state, either Lsd1 or Jmjd1a alone or both enzymes simultaneously are recruited to target promoters (Metzger et al., 2005; Zamane et al., 2006; Garcia Bassetts et al., 2007). (C) The AR can also overcome repression imposed by H3K9me3 by joined recruitment of Jmjd2c and Lsd1 that subsequently transform H3K9me3 into the unmethylated state. H3T11-phosphorylation by Prk1 facilitates removal of the trimethylated form (Metzger etal., 2005, Wissmann et al., 2007; Metzger et al., 2008). (D) The deubiquitinating enzyme $2 A-D u b$ is targeted to $A R$ responsive genes and in concert with H3K9 HDMs and H3K4 HMTs establishes an open chromatin configuration (Zhu et al., 2007; Zhou et al., 2008). Solid arrows indicate enzymatic actions adding PTMs, dotted arrows symbolize removal of the indicated groups, and dashed arrows demonstrate synergistic pathways. 
cells and defective posterior development in Xenopus laevis (Joo et al., 2007).

\section{Polycomb-mediated silencing: current model and open questions}

Based on the studies reviewed in the previous sections, it is clear that in mammalian genomes the transcriptional status and associated chromatin configuration of genes are strongly connected to the GC status of the underlying promoter sequence. In ES cells and some other cell types, Polycomb group proteins suppress predominantly $\mathrm{H} 3 \mathrm{~K} 4$-methylated $\mathrm{CpG}$ island promoters. Presence of components of both PRC complexes and associated marks is associated with efficient repression, whereas PRC1 occupancy alone is compatible with transcription. This argues that the actual relative enrichments of active and repressive modifications and associated proteins determine the transcriptional outcome. Accordingly, PRC2 and PRC1 seem to cooperate to counteract the "default" presence of H3K4 methylation. PRC2 contributes to silencing by recruiting H3K4 HDMs, thereby regulating the homeostasis of the bivalent state. Furthermore, $\mathrm{PRC} 2$ facilitates $\mathrm{PRC} 1$ targeting by providing the $\mathrm{H} 3 \mathrm{~K} 27 \mathrm{me} 3$ binding site (Fig. 3).

To fully understand PcG mediated silencing at $\mathrm{CpG}$ island genes, several questions need to be addressed. First, it is unclear how and which H3K4 HMTs are targeted to CpG-rich promoters. Besides promoter specific transcription factors, we envision a role for the CxxC motifs present in MII1, MII2 and CFP1 in target selection. A second point is whether bivalent genes are regulated by MII family members only, or also by the hSet1a/b HMTs. Further questions remain. What directs the targeting of $\mathrm{PRC} 2$ and $\mathrm{PRC} 1$ to $\mathrm{CpG}$ island promoters? Is targeting facilitated by interactions with MII HMTs? Are there mechanistic differences in the establishment versus maintenance of bivalency? We must determine to what extent PRC1 repression in vivo is mediated by suppression of nucleosome remodeling versus blocking of RNAPII elongation by H2AK119ub1. Finally, future work should be directed to understand the interplay between HMTs, HDMs and sequence specific transcription factors in the maintenance of the repressed bivalent state versus resolution into either an active or repressed state.

\section{Transcriptional repression by H3K9 methylation}

Nuclear hormone receptors (NHRs) constitute a group of small molecule activated transcription factors that control important physiological and developmental pathways (Evans, 1988). They exert their function upon binding of their cognate ligand and the subsequent recruitment of transcriptional co-factor complexes (Perissi and Rosenfeld, 2005; Rosenfeld and Glass, 2001). The research on NHRs over the past two decades pioneered our current understanding that transcription factors are DNA binding modules that upon recruitment of transcriptional co-factors determine the outcome of transcription initiation (Chambon, 2005; Evans, 2005). Genome wide ChIP-on-chip analyses have defined distinct histone lysine modification patterns along transcribed or repressed genes (Barski et al., 2007; Mikkelsen et al., 2007), but the involvement of HMTs and HDMs in hormone regulated transcription was investigated in more detail only lately. In the follow- ing chapter, case studies analyzing transcriptional control by steroid hormone receptors are reviewed, and the emerging picture at hormone regulated promoters is presented. An important observation is that most HMTs and all HDMs associated with nuclear hormone receptors target $\mathrm{H} 3 \mathrm{~K} 4$ and $\mathrm{H} 3 \mathrm{~K} 9$, so far excluding Polycomb repressive complexes from the prototype response pathway of NHRs (Fig. 4).

\section{Transcriptional control by the estrogen receptor}

Transcription of androgen and estrogen receptor target genes is very rapidly activated upon exposure to the cognate ligand, dihydrotestosterone or estradiol. If no ligand is present, steroid hormone receptors reside in the cytoplasm. However, trace amounts of receptors seem to stay associated with their target genes even in the unliganded conformation. In a recent publication, the group of Michael Rosenfeld described the formation of complexes between unliganded estrogen receptor $(E R \alpha)$ and repressive HMTs as a requirement to prevent activation by unliganded nuclear receptors, a situation they refer to as the "Gatekeeper model" (Garcia-Bassets et al., 2007). They discovered that unliganded $E R \alpha$ is associated with HMTs (such as Riz1, Glp and Eset) that catalyze repressive $\mathrm{H} 3 \mathrm{~K} 9 \mathrm{me} 2$ when bound to DNA, ensuring prevention of spurious transcription (Fig. 4A). They also observe ligand-activated recruitment of the H3K9me2specific HDM Lsd1 by the estrogen receptor, demonstrating how hormonal stimulation mediates removal of repressive marks at endogenous ER $\alpha$ target genes (Garcia-Bassets et al., 2007), after which recruitment of associated co-activators occurs (Metivier et al., 2003). Interestingly, they show employment of the same molecular strategy at distinct $\mathrm{ER} \alpha$ target genes using different combinations of H3K9 HMTs and HDMs (G9a and Jmjd1a, respectively; Fig. 4A, bottom), underscoring the importance of promoter architecture for a given transcriptional readout. The same code seems to exist for other signal-regulated transcription programs such as NF- $\mathrm{KB}$ and C/EBP mediated transcription (Garcia-Bassets et al., 2007). The activation function of Lsd1 in the context of ER $\alpha$ mediated transcription has recently been extended (Perillo et al., 2008). They show that receptor targeted demethylation of $\mathrm{H} 3 \mathrm{~K} 9 \mathrm{me} 2$ triggers a favorable alteration of the DNA conformation at promoters by the demethylation byproduct hydrogen peroxide (Fig. 4A), thus using controlled DNA damage and repair to guide productive transcription.

\section{The androgen receptor and histone demethylases}

Posttranslational modifications associated with androgen receptor (AR) mediated transcription have been studied in more detail. Besides the above mentioned "gatekeeper" situation, in which the AR recruits HMTs Eset and Riz1 (Fig. 4B), no further interaction with HMTs is known. However, a special interest has arisen in the transcriptional activation by AR due to recruitment of different members of the HDM superfamily. Initially, it was shown that agonist-dependent recruitment of Lsd1 resulted in local decrease of $\mathrm{H} 3 \mathrm{~K} 9 \mathrm{me} 2$ concomitant with transcriptional activation of AR target genes (Metzger et al., 2005) (Fig. 4B). The histone de-methylase Jhdm2a is recruited to AR targets in a hormonedependent manner and functions independent of and in parallel to Lsd1 in the clearance of H3K9me2/3, facilitating AR-mediated transcription (Yamane et al., 2006) (Fig. 4B). Wissmann and colleagues have further shown that demethylases Lsd1 and 
Jmjd2c cooperatively bind to agonist activated AR and catalyze the reversal of $\mathrm{H} 3 \mathrm{~K} 9 \mathrm{me} 3$-imposed repression at several $\mathrm{AR}$ target genes (Wissmann et al., 2007). Moreover, simultaneous phosphorylation of H3T11 by the Prk1 kinase efficiently enhances the demethylation potential of Jmjd2c (Metzger et al., 2008), demonstrating that specific gene regulation events require assembly and coordination of co-factors with different substrate specificities (Fig. 4C). According to their function in AR target gene activation, elevated expression levels of either Lsd1, Prk1 or Jmjd2c in prostate tissue is directly correlated with the malignancy of prostate tumors (Kahl et al., 2006; Wissmann et al., 2007; Schulte et al., 2009). Additionally, members of the JMJD family of HDMs, Jmjd2a and Jmjd2d de-methylate H3K9me3/2, $\mathrm{H} 3 \mathrm{~K} 36 \mathrm{me} 3 / 2$ and $\mathrm{H} 3 \mathrm{~K} 9 \mathrm{me} 3 / 2 / 1$ in vitro, and are both found to interact with and co-activate the AR (Shin and Janknecht, 2007a; Shin and Janknecht, 2007b). Finally, also the H3K9me2/1 HDM Jmjd1c was identified as an AR interacting protein that potentiates ligand activated AR transcription (Wolf et al., 2007). An interesting aspect concerns transcriptional regulation by H2AK119ub1. Zhu and colleagues described recruitment of a deubiquitinating enzyme by $A R$, adding to the emerging picture of AR recruiting a co-activator complex to remove general repressive marks (Zhu et al., 2007) (Fig. 4D). The implication of parallel pathways of ubiquitination and methylation has been discussed above in more detail. Future research will have to identify the signaling events that determine co-factor assembly and exchange and decide whether or which HMTs and HDMs are recruited to given target promoters.

\section{Directed repression}

The nuclear orphan receptor interacting protein small heterodimerization partner (SHP) has the ability to inhibit transcription of many NHRs by formation of repressive heterodimers. Inhibiting proper binding to target genes, SHP-mediated repression mechanistically depends on the direct recruitment of HDAC1, chromatin re-modelers and the G9a H3K9 methyltransferase (Boulias and Talianidis, 2004; Fang et al., 2007). One well characterized target of SHP-mediated repression is Cyp7a, a key gene in bile acid biosynthesis, and a recent report demonstrated that G9a mediated methylation of histones is part of a functional interplay between several chromatin-modifying enzymes (Fang et al., 2007).

\section{Facilitated transcription}

During activated transcription, transcription factors directly recruit co-activators towards the site of RNAPII binding, resulting in local chromatin changes such as histone acetylation or H3K4me. The first case of recruitment of activating HMTs by a NHR has been described in Drosophila, where ecdysone treatment results in directed hyper-methylation of H3K4 by the fly orthologue of MII (Sedkov et al., 2003). In mammals, the estrogen and Vitamin D receptor recruit the MII1/2 H3K4-methyltransferase complex to target promoters by direct interaction with the complex component Menin in a ligand-dependent manner (Dreijerink et al., 2006; Mo et al., 2006). Recruitment of the MIl1/2 complex in turn leads to strong enrichment of $\mathrm{H} 3 \mathrm{~K} 4 \mathrm{me} 3$ at the transcription start site (Barski et al., 2007). A recent study identified Mll2 as a direct interaction partner of the hematopoietic transcriptional activator NF-E2 that guides MII2 association to the $\beta$-globin locus (Demers et al., 2007). MIl2 gene deficient animals die at early embryogenesis (Glaser et al., 2006), and defects suggest a crucial involvement in developmentally regulated genes rather than in estrogen or Vitamin $D$ regulated maintenance pathways.

Lee and co-workers have shown that steroid hormone receptors $A R$ and $E R \alpha$ have a common co-activator complex consisting of TIF2, CBP, CARM1 and, surprisingly, of the HMT G9a that usually functions in euchromatic repression. The co-activator complex functions synergistically and depends on repression of the G9a HMT activity by association with TIF2, suggesting that G9a functions as a structural component (Lee et al., 2006a). A similar finding identified the $\mathrm{H} 3 \mathrm{~K} 9$ methyltransferase Riz1 as a coactivator selectively for the estrogen and the progesterone receptor, and consequently Riz1 gene deficient animals display reduced hormone response in female reproductive tissues (Carling et al., 2004). For both cases, however, the mechanistic contribution of $\mathrm{H} 3 \mathrm{~K} 9$ methylation to transcriptional activation is not understood.

The HMT Nsd1 interacts with several members of the NHR superfamily (Huang et al., 1998). Nsd1 contains separable activation and repression domains, suggesting that $\mathrm{H} 3 \mathrm{~K} 36 \mathrm{me}$ might not only be responsible for transcription elongation alone (Barski et al., 2007; Rayasam et al., 2003). These findings once more underscore the importance of sequence environment and partner proteins in the determination of the transcriptional readout.

\section{Regulation of NHR mediated epigenomics}

According to the published information, recruitment of PcG proteins is not linked to NHRs, instead hormonally regulated gene repression and activation depends mainly, if not exclusively, on the H3K9me and H3K4me pathways. In contrast to other transcription factors described above, chromosome-wide mapping studies of ER and $A R$ binding revealed that their response elements are mainly enhancer-associated, and the consensus sites are unaffected by potential CpG methylation (AGAACA and AGGTCA, respectively) (Carroll et al., 2005; Massie et al., 2007). However, the genomic approach also revealed that both NHRs bind to a significant amount of non-canonical response elements, requiring a more detailed analysis on the potential influence of GC density and DNA methylation on binding of transcription factors and chromatin modifying enzymes. Interestingly, the two studies revealed a significant overlap of androgen responsive elements with binding sites for transcription factors of the ETS1 family (Massie et al., 2007), and of estrogen responsive elements with recognition motifs for the forkhead protein FoxA1 (Carroll et al., 2005), adding another layer of complexity to transcription factor binding site recognition and recruitment to DNA.

Many reports demonstrate that HDMs and HMTs are part of several multiprotein complexes and thus might be indirectly targeted to many more transcription factors than known to date. For instance, arginine methylation of co-factors themselves was shown to play an important role in the regulation of transcriptional initiation (Mostaqul Huq et al., 2006; Xu et al., 2001; Xu et al., 2004). Several non-histone proteins have been identified to be lysine methylated (Huang and Berger, 2008), also including nuclear hormone receptors. Notably, trimethylation of the retinoid acid receptor facilitates recruitment of co-activator complexes (Huq et al., 2007); and Set7/9 stabilizes ER $\alpha$ leading to more efficient recruitment of ER to its target genes and facilitating their 


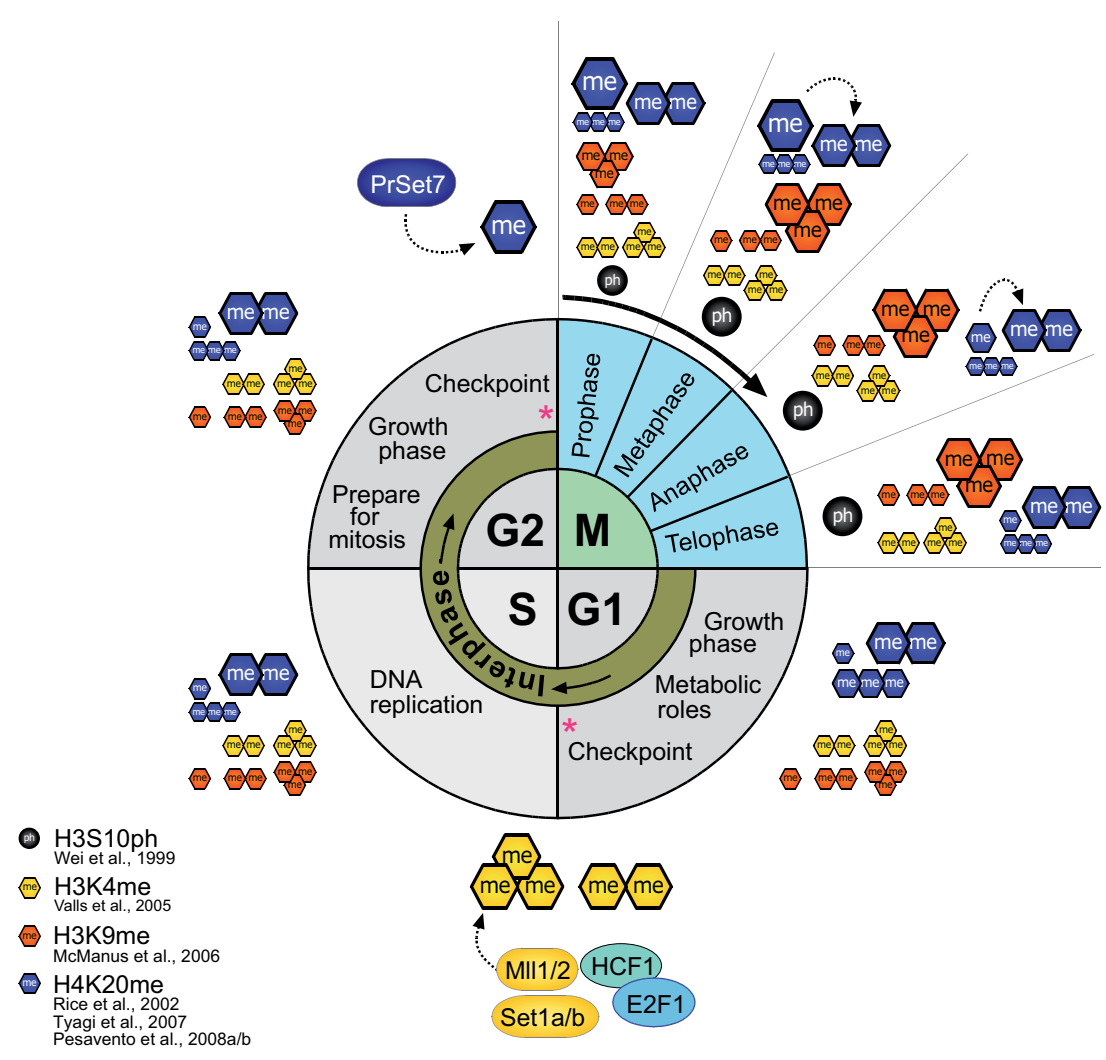

Fig. 5. Histone methylation during the cell division cycle. $H 3 K 4 m e 2 / 3$ remains mainly constant during all steps of the cell division cycle. At the $G 1$ to $S$ phase transition, MIl and Set 1 complexes are recruited by E2F and HCF1 transcription factors, mediating transcriptional activation of their target genes. $\mathrm{H} 3 \mathrm{~K} 9 \mathrm{me} 1 / 2$ remains constant during the cell cycle, only H3K9me3 has a sharp peak at the transition of late $\mathrm{G} 2$ to mitosis as revealed by immunofluorescence analyses. H4K20me1 strongly peaks at the G2 to M transition but is rapidly converted to dimethylated H4K20. H4K2Ome2 levels remain unchanged high at all stages of the cell cycle, and H4K2Ome3 only slightly peaks at early G1. All H4K2Ome states were characterized by top down mass spectrometric analyses. The sizes of histone methylation hexagons correspond to their respective levels.

activation (Subramanian et al., 2008). These data demonstrate that methyltransferases and demethylases take part in a multitude of transcriptional regulatory pathways, and that they are even more versatile modulators of gene expression than anticipated. Besides the ongoing characterization of major methylation pathways, future research should aim to integrate genome wide transcription factor binding, histone lysine methylation patterns and HMT/HDM occupancy in a systems biology approach to delineate physiologic regulatory pathways and networks of interlaced co-factor complexes.

\section{Histone methylation and the control of the cell division cycle}

Mitotically regulated genes are very dynamically expressed, and additional regulatory steps must ensure successful genome duplication and segregation. The most characteristic posttranslational modification to be found associated with mitotic chromatin is H3S10P, being essential for proper condensation and segregation (Wei et al., 1999). More recently, systematic analyses on synchronized cultured cells showed that several other chromatin modifications are dynamically altered during the cell division cycle, generating specific chromatin signatures at different stages of mitosis and interphase (Fig. 5). Valls and colleagues analyzed the occurrence of $\mathrm{H} 3 \mathrm{~K} 4 \mathrm{me} 2 / 3$ during mitosis and describe a possible impact of $\mathrm{H} 3 \mathrm{~K} 4 \mathrm{me} 2 /$ 3 on mitotic inheritance. They show that global H3K4me2/3 levels largely do not change between interphase and mitosis, and further demonstrate that $\mathrm{H} 3 \mathrm{~K} 4 \mathrm{me} 2 / 3$ marks are maintained at promoters of target genes during mitosis (Valls et al., 2005). Moreover, they observe transcription coupled increase of $\mathrm{H} 3 \mathrm{~K} 4 \mathrm{me} 3$ during mitosis at the actively transcribed cyclin B1 promoter, suggesting that HMTs are maintained as active enzymes during mitosis (Valls et al., 2005) (Fig. 5). A second study analyzing $\mathrm{H} 3 \mathrm{~K} 9$ methylation states by immunofluorescence revealed a sharp increase of $\mathrm{H} 3 \mathrm{~K} 9 \mathrm{me} 3$ in the transition from late G2 into mitosis, whereas H3K9me1/2 remained largely constant (McManus et al., 2006). Interestingly, the peak of H3K9me3 rapidly decreased to interphase levels after completion of mitosis, demonstrating distinct cell cycle dynamics for H3K9 methylation (Fig. 5) (McManus et al., 2006). However, the biological function of elevated H3K9me3 levels that obviously are not meant for the formation of heterochromatic regions remains elusive. The group of Craig Mizzen analyzed the H4K2O methylation pattern during the cell division cycle using metabolic labeling and a topdown mass spectrometry (TDMS) approach (Pesavento et al., 2008a; Pesavento et al., 2008b). They show that throughout all stages of the cell cycle the vast majority of $\mathrm{H} 4$ is di-methylated at lysine 20 (Fig. 5). In mitosis, global deacetylation of $\mathrm{H} 4$ follows an initial transient peak of H4K20me1 directly after $\mathrm{S}$ phase when new histone $\mathrm{H} 4$ is incorporated into newly replicated DNA (Karachentsev et al., 2007; Pesavento et al., 2008b; Scharf et al., 2009). However, all H4K20 methylation seems to be highly progressive, and $\mathrm{H} 4 \mathrm{~K} 20 \mathrm{me} 1$ is subsequently processed into $\mathrm{H} 4 \mathrm{~K} 20$ me2. Only a minor fraction of H4K2O is tri-methylated, and this occurs mainly at the G1 phase (Fig. 5). Their unbiased approach revealed that all H4K20 methylation occurs in overlapping windows extending from mid-G2 until mid-G1 (Pesavento et al., 2008b). The authors furthermore demonstrate that H4K20 methylation is stable and does not turn over at an appreciable rate in vivo (Pesavento et al., 2008b), a finding that is consistent with the fact that no H4K20 HDM has been discovered to date.

\section{H4K20 methylation and S-phase progression}

PrSet7/SET8 is the only enzyme known to catalyze the transfer of mono-methyl groups to H4K20 (Nishioka et al., 2002, Rice et al., 2002; Xiao et al., 2005). Increased expression of PrSet7 and H4K20me1 during G2 and M phase at chromatin condensation/ segregation was discovered, and an inverse correlation between H4K20me1 and H4K16Ac was reported (Houston et al., 2008; Rice et al., 2002). Several studies associate PrSet7 activity with 
Proliferation

A
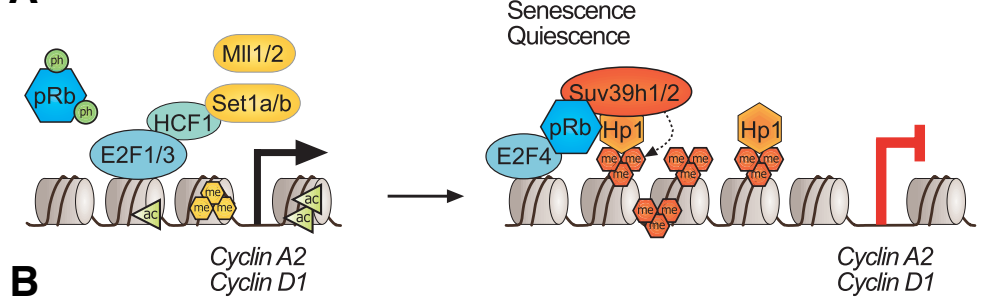

Cyclin A2 Cyclin D1

Myoblast
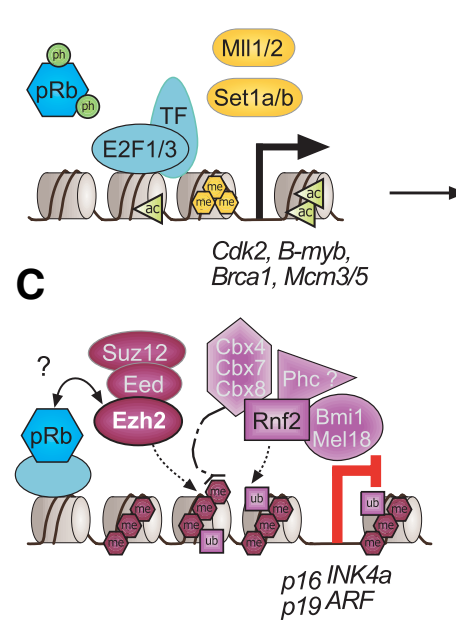

Senescence

Quiescence

Cell cycle exit

Terminally differentiated myotube Irreversible cell cycle exit
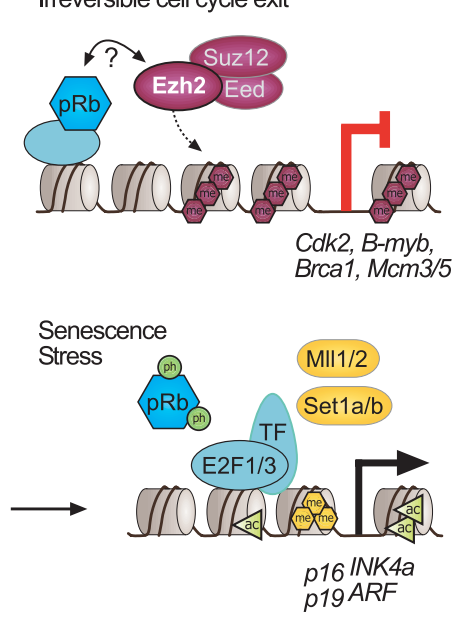

Fig. 6. Suv39h versus Polycomb signaling during the cell division cycle. (A) Cellular senescence or quiescence is mainly maintained by the canonical Suv39h/HP1/Suv4-20h pathway, establishing heterochromatic stretches that are characterized by H3K9me3 and H4K2Ome3. (B) Terminal differentiation in myoblast cells depends on Ezh2-mediated H3K27me3, while H3K9me3 levels are not altered. Presence of $p R b$ is required, but a direct interaction between $p R b$ and PRC2 members has not been established so far. (C) Cellular proliferation depends on the silencing of the Ink4 locus. pRb recruited Ezh2/H3K27me3 establishes the binding site for the PRC1 complex, that yields H2AK119ub1 and silences the Ink4 locus. Senescence, stress or tumorigenic transformations trigger loss of K27me3 and Ink4 genes are transcribed, resulting in cell cycle exit due to pRb hypo-phosphorylation.

the control of S-phase progression (Jorgensen et al., 2007; Tardat et al., 2007). The interaction of PrSet7 with PCNA could be an explanation of how H4K20me1 can be maintained during cell division (Huen et al., 2008). siRNA knockdown of PrSet7 results in improper DNA replication (Tardat et al., 2007), in an increased number of cells in S/G2 (Huen et al., 2008), and in global chromosome condensation failure, aberrant centrosome amplification and substantial DNA damage (Houston et al., 2008). Moreover, PrSet7 gene deficient animals die early during embryogenesis (Huen et al., 2008; Oda et al., 2009). Escaping PRSet7 null flies display strongly reduced H4K20me1 at third instar larvae, an delay in early mitotic stages, and defects in proper chromosome condensation; and surviving cells suffer from cell death and enriched cellular DNA content (Karachentsev et al., 2005; Sakaguchi and Steward, 2007). These studies, combined with the finding that PrSet7 expression (and thus also H4K20me1) is directly controlled by the cell cycle regulator HCF1 (Julien and Herr, 2004), suggest an important function of PrSet7 in the control of proper S-phase progression. However, in contrast to some of the above reported results, the TDMS approach of Pesavento et al. revealed no interdependence of H4K20me and H4K16Ac. In addition, they showed that siRNA mediated knockdown of PrSet7 has no effect on cell cycle progression, and that the majority of $\mathrm{H} 4 \mathrm{~K} 20$ me1 is added only postmitotic, questioning the essential role of PrSet7 in the control of S-phase progression in vitro (Pesavento et al., 2008b). It is interesting to note that PrSet7 was recently shown to mono-methylate p53 and to down-regulate its transcription activation function of highly responsive target genes. By doing so, PrSet7 functions as an ameliorator of p53-function in response to DNA damage, and consistently PrSet7 expression itself is downregulated upon massive DNA damage (Shi et al., 2007). Taken together, to fully understand the impact of PrSet7, detailed analyses of PrSet7 conditional mutants are required to estimate the effect of H4K20me1 on on cell cycle control and chromatin integrity. H4K20me2/3 is catalyzed by the Suv4-20h1/2 enzymes (Schotta et al., 2004; Yang et al., 2008). However, these modifications do not seem to play a role during the cell cycle, and the global abundance of H4K20me2 suggests a neutral effect on gene transcription (Pesavento et al., 2008b).

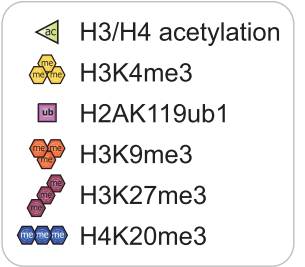

\section{H3K4 methylation during the cell cycle}

Besides their function in transcriptional regulation of the Hox cluster (Ansari et al., 2008), MII proteins and associated cofactors participate in the regulation of the cell division cycle (Fig. 5). For instance, Menin was found to target Mll1/2 to the promoters of cyclindependent kinase inhibitors p27Kip1 and Ink4c ${ }^{\text {18 }}$, enhancing their transcription (Milne et al., 2005b); however, the responsible stimulating pathways and signals remain unidentified. The HMT activities of MIl1 and Set1 were found to be recruited by the cell cycle regulators HCF1 and E2F (Narayanan et al., 2007; Tyagi et al., 2007), inducing cell cyclespecific transcriptional activation at the $\mathrm{G} 1$ to $S$ phase transition by H3K4me (Tyagi et al., 2007).

\section{Repressive modifications in the control of cell cycle and senescence}

The balance between cell proliferation and differentiation is controlled during early $\mathrm{G} 1$ by the transcription factors $p R b / E 2 F$ (Planas-Silva and Weinberg, 1997). Cellular senescence is controlled by repressive histone modifications, and the transcription factors E2F4/pRb are known to recruit the Suv39h HMTs to quiescence and senescence related silenced loci, establishing the H3K9me3-HP1 axis of heterochromatinization at growth promoting genes (Narita et al., 2003; Nielsen et al., 2001). During cell cycle exit (and not in cycling cells) specific E2F4/pRb target promoters, such as cyclins $D 1$ and $A 2$, gain $\mathrm{H} 3 \mathrm{~K} 9 \mathrm{me} 3$, and this differentiation-associated modification is strictly depending on Suv39h1 (Ait-Si-Ali et al., 2004) (Fig. 6A). Also, Suv39h1 was shown to function as a tumor suppressor that controls oncogeneinduced senescence by $\mathrm{H} 3 \mathrm{~K} 9 \mathrm{me} 3$, further underscoring the func- 
tional importance of histone methylation in the regulation of cellular states (Braig et al., 2005). It is, however, not clear whether this silencing is permanent or dynamic, given that the activity of H3K9 HDMs during the G0 state of the cell division cycle has not been analyzed.

A recent report described an additional pathway, in which gain of H3K27me3 closely correlates with the terminal differentiation of proliferating myoblasts into multinucleated myotubes (Blais et al., 2007) (Fig. 6B). Targeting of H3K27me to $\mathrm{pRb}$ regulated cell cycle genes establishes a repressive chromatin signature that is required for permanent and irreversible cell cycle exit. Target genes comprise Cdk2, B-myb, Brca1 and $M c m 3 / 5$, and all of them gain H3K27me3 only upon differentiation of myoblasts into multinucleated myotubes (Blais et al., 2007), whereas H3K9me is either not participating in this pathway or its levels remain unaltered in comparison to myoblasts. The authors also show that pRbdependent (and also pRb-independent) H3K27 methylation at myogenic target genes is context dependent and specific to permanently arrested cells (Blais et al., 2007) (Fig. 6B).

Important regulators of the $\mathrm{G} 1$ to $S$ transition in response to anti-mitogenic signaling pathways are the Ink4 family members of CDK-inhibitors (Fig. 6C). Expression of Ink4 results in pRb hypophosphorylation and ultimately yields $\mathrm{G} 1$ arrest. The connection of Polycomb-mediated silencing with cell cycle regulation, control of the senescence checkpoint and cancer formation was originally identified generating animals that are deficient for the PRC1 member Bmi1. The study demonstrated that $\mathrm{p} 16^{\mathrm{INK} 4 a}$ and $\mathrm{p} 19^{\mathrm{ARF}}$ are critical in vivo targets of PRC1 mediated silencing (Jacobs et al., 1999). The interconnection between E2F/pRb and Polycombmediated repression was further corroborated by studies revealing that silencing of the $p 16^{\text {NKK4a }}$ locus by H3K27me3 methylation, in concert with associated binding of PRC2 and PRC1 members, strictly depends on pRb (Bracken et al., 2003; Kotake et al., 2007). Continuous presence of Ezh2 at the Ink4 locus is required for ongoing cell divisions; and stress, senescence and tumorigenic transformation coincide with decreased levels of associated H3K27me3, establishing Ezh2 as a gatekeeper of cell division control (Bracken et al., 2007). It is however unclear, how the choice of $\mathrm{pRb}$ to either recruit Ezh2 (Blais et al., 2007) or Suv39h (Nielsen et al., 2001; Ait-Si-Ali et al., 2004) is accomplished. Although all these data indicate that pRb-binding is the prime requirement for $\mathrm{H} 3 \mathrm{~K} 27 \mathrm{me} 3$ methylation at $\mathrm{pRb}$ target promoters, a direct interaction between Ezh2 and $\mathrm{pRb}$ has not been established and the mechanism of targeting remains unclear (Fig. 6C).

The role of histone demethylases in the control of the cell division cycle is less well understood. The HDM Jarid1a/Rbp2 removes active $\mathrm{H} 3 \mathrm{~K} 4 \mathrm{me} 3 / 2$ and was reported to physically interact with pRb (Christensen et al., 2007; Klose et al., 2007), further strengthening the link between $\mathrm{pRb}$ and transcriptional repression. However, while in both studies only the effect of Rbp2 on the Hox cluster of genes was analyzed, the regulation of bona fide $\mathrm{pRb}$ targets and cell cycle regulators needs further investigation. Jmjd2a demethylates H3K9me3/2 and H3K36me3/2 to the unmethylated state (Shin and Janknecht, 2007a). Jmjd2a was reported to interact with HDACs and the retinoblastoma protein, and mediates repression of E2F regulated promoters (Gray et al., 2005). In which way demethylation of H3K9 or H3K36 should assist transcriptional repression, though, is unclear. An easy explanation would be that Jmjd2a acts merely as an architectural factor at $\mathrm{pRb}$ responsive targets, but further experimental evidence is necessary to evaluate the influence of HDMs in the control of cell cycle regulated genes.

\section{Outlook}

Recent epigenomic profiling and functional studies have provided insight in the dynamics and regulatory complexity of transcriptional repression, mediated by histone modifying enzymes like HMTs, HDMs, E3 ubiquitin ligases, ubiquitin-specific proteases and other chromatin associated proteins. It is becoming increasingly clear that these machineries function in a sequence dependent manner. Furthermore, the repressed chromatin state is not static but dynamic and reflects the homeostasis between antagonistic enzymatic activities. To truly understand the role of chromatin in transcriptional regulation, it will be necessary to integrate the relative levels of antagonistic histone modifications and their spatial distributions in relation to transcription factor binding sites and RNAPII into the equation. Finally, systematic loss- and gain-of-function experiments are required to dissect the mechanistic hierarchy between the different chromatin and epigenetic modifiers at different stages of development. Beyond doubt, many exciting years are ahead of us.

\section{Acknowledgements}

We apologize to all authors whose work could not be cited due to space limitation. We also regret that we cited some reviews instead of the original reports due to the broad nature of this article. P.H. was supported by an EMBO long-term postdoctoral fellowship and M.A. was funded by a Boehringer Ingelheim PhD fellowship. Research at the Friedrich Miescher Institute is supported by the Novartis Research Foundation, research in the Peters laboratory is supported by the EU NoE network grant 'The Epigenome' (LSHG-CT-2004-503433).

\section{References}

AGGER, K., CHRISTENSEN, J., CLOOS, P.A. and HELIN, K. (2008). The emerging functions of histone demethylases. Curr Opin Genet Dev. 18: 159-168.

AGGER, K., CLOOS, P.A., CHRISTENSEN, J., PASINI, D., ROSE, S., RAPPSILBER, J., ISSAEVA, I., CANAANI, E., SALCINI, A.E. and HELIN, K. (2007). UTX and JMJD3 are histone H3K27 demethylases involved in HOX gene regulation and development. Nature 449: 731-734.

AIT-SI-ALI, S., GUASCONI, V., FRITSCH, L., YAHI, H., SEKHRI, R., NAGUIBNEVA, I., ROBIN, P., CABON, F., POLESSKAYA, A. and HAREL-BELLAN, A. (2004). A Suv39h-dependent mechanism for silencing S-phase genes in differentiating but not in cycling cells. EMBO $J$ 23: 605-615.

ALLEN, M.D., GRUMMITT, C.G., HILCENKO, C., MIN, S.Y., TONKIN, L.M., JOHNSON, C.M., FREUND, S.M., BYCROFT, M. and WARREN, A.J. (2006). Solution structure of the nonmethyl-CpG-binding CXXC domain of the leukaemia-associated MLL histone methyltransferase. EMBO J 25: 4503-4512.

ANSARI, K.I., MISHRA, B.P. and MANDAL, S.S. (2008). Human CpG binding protein interacts with MLL1, MLL2 and hSet1 and regulates Hox gene expression. Biochim Biophys Acta 1779: 66-73.

AYTON, P.M., CHEN, E.H. and CLEARY, M.L. (2004). Binding to nonmethylated CpG DNA is essential for target recognition, transactivation, and myeloid transformation by an MLL oncoprotein. Mol Cell Biol 24: 10470-10478.

BAJIC, V.B., TAN, S.L., CHRISTOFFELS, A., SCHONBACH, C., LIPOVICH, L., YANG, L., HOFMANN, O., KRUGER, A., HIDE, W., KAI, C. et al. (2006). Mice and men: their promoter properties. PLoS Genet 2: e54.

BARSKI, A., CUDDAPAH, S., CUI, K., ROH, T.Y., SCHONES, D.E., WANG, Z., WEI, G., CHEPELEV, I. and ZHAO, K. (2007). High-resolution profiling of histone methylations in the human genome. Cell 129: 823-837.

BeJerano, G., PHEAsant, M., MAKUnin, I., StePHEN, S., KENT, W.J., 
MATTICK, J.S. and HAUSSLER, D. (2004). Ultraconserved elements in the human genome. Science 304: 1321-1325.

BERNSTEIN, B.E., MIKKELSEN, T.S., XIE, X., KAMAL, M., HUEBERT, D.J., CUFF, J., FRY, B., MEISSNER, A., WERNIG, M., PLATH, K. et al. (2006a). A bivalent chromatin structure marks key developmental genes in embryonic stem cells. Cell 125: 315-326.

BERNSTEIN, E., DUNCAN, E.M., MASUI, O., GIL, J., HEARD, E. and ALLIS, C.D. (2006b). Mouse polycomb proteins bind differentially to methylated histone $\mathrm{H} 3$ and RNA and are enriched in facultative heterochromatin. Mol Cell Biol 26: 2560-2569.

BIRKE, M., SCHREINER, S., GARCIA-CUELLAR, M.P., MAHR, K., TITGEMEYER, F. and SLANY, R.K. (2002). The MT domain of the proto-oncoprotein MLL binds to $\mathrm{CpG}$-containing DNA and discriminates against methylation. Nucleic Acids Res 30: 958-965.

BLAIS, A., VAN OEVELEN, C.J., MARGUERON, R., ACOSTA-ALVEAR, D. and DYNLACHT, B.D. (2007). Retinoblastoma tumor suppressor protein-dependent methylation of histone $\mathrm{H} 3$ lysine 27 is associated with irreversible cell cycle exit. J Cell Biol 179: 1399-1412.

BOULIAS, K. and TALIANIDIS, I. (2004). Functional role of G9a-induced histone methylation in small heterodimer partner-mediated transcriptional repression. Nucleic Acids Res 32: 6096-6103.

BOYER, L.A., PLATH, K., ZEITLINGER, J., BRAMBRINK, T., MEDEIROS, L.A., LEE, T.I., LEVINE, S.S., WERNIG, M., TAJONAR, A., RAY, M.K. et al. (2006). Polycomb complexes repress developmental regulators in murine embryonic stem cells. Nature 441: 349-353.

BRACKEN, A.P., KLEINE-KOHLBRECHER, D., DIETRICH, N., PASINI, D., GARGIULO, G., BEEKMAN, C., THEILGAARD-MONCH, K., MINUCCI, S., PORSE, B.T., MARINE, J.C. et al. (2007). The Polycomb group proteins bind throughout the INK4A-ARF locus and are disassociated in senescent cells. Genes Dev 21: 525-530.

BRACKEN, A.P., PASINI, D., CAPRA, M., PROSPERINI, E., COLLI, E. and HELIN, K. (2003). EZH2 is downstream of the pRB-E2F pathway, essential for proliferation and amplified in cancer. EMBO $J$ 22: 5323-5335.

BRAiG, M., LEE, S., LODDENKEMPER, C., RUDOLPH, C., PETERS, A.H., SCHLEGELBERGER, B., STEIN, H., DORKEN, B., JENUWEIN, T. and SCHMITT, C.A. (2005). Oncogene-induced senescence as an initial barrier in lymphoma development. Nature 436: 660-665.

BROWN, J.L., FRITSCH, C., MUELLER, J. and KASSIS, J.A. (2003). The Drosophila pho-like gene encodes a YY1-related DNA binding protein that is redundant with pleiohomeotic in homeotic gene silencing. Development 130: 285294.

BROWN, J.L., MUCCI, D., WHITELEY, M., DIRKSEN, M.L. and KASSIS, J.A. (1998). The Drosophila Polycomb group gene pleiohomeotic encodes a DNA binding protein with homology to the transcription factor YY1. Mol Cell 1: 10571064.

BUCHWALD, G., VAN DER STOOP, P., WEICHENRIEDER, O., PERRAKIS, A., VAN LOHUIZEN, M. and SIXMA, T.K. (2006). Structure and E3-ligase activity of the Ring-Ring complex of polycomb proteins Bmi1 and Ring1b. EMBO J 25: 2465-2474.

CAO, R., TSUKADA, Y. and ZHANG, Y. (2005). Role of Bmi-1 and Ring1A in H2A ubiquitylation and Hox gene silencing. Mol Cell 20: 845-854.

CARLING, T., KIM, K.C., YANG, X.H., GU, J., ZHANG, X.K. and HUANG, S. (2004). A histone methyltransferase is required for maximal response to female sex hormones. Mol Cell Biol 24: 7032-7042.

CARLONE, D.L. and SKALNIK, D.G. (2001). CpG binding protein is crucial for early embryonic development. Mol Cell Biol 21: 7601-7606.

CARROLL, J.S., LIU, X.S., BRODSKY, A.S., LI, W., MEYER, C.A., SZARY, A.J., EECKHOUTE, J., SHAO, W., HESTERMANN, E.V., GEISTLINGER, T.R. et al. (2005). Chromosome-wide mapping of estrogen receptor binding reveals longrange regulation requiring the forkhead protein FoxA1. Cell 122: 33-43.

CHAMBON, P. (2005). The nuclear receptor superfamily: a personal retrospect on the first two decades. Mol Endocrinol 19: 1418-1428.

CHO, Y.W., HONG, T., HONG, S., GUO, H., YU, H., KIM, D., GUSZCZYNSKI, T., DRESSLER, G.R., COPELAND, T.D., KALKUM, M. et al. (2007). PTIP associates with MLL3- and MLL4-containing histone $\mathrm{H} 3$ lysine 4 methyltransferase complex. J Biol Chem 282: 20395-20406.
CHRISTENSEN, J., AGGER, K., CLOOS, P.A., PASINI, D., ROSE, S., SENNELS, L., RAPPSILBER, J., HANSEN, K.H., SALCINI, A.E. and HELIN, K. (2007). RBP2 belongs to a family of demethylases, specific for tri-and dimethylated lysine 4 on histone 3. Cell 128: 1063-1076.

CLOOS, P.A., CHRISTENSEN, J., AGGER, K. and HELIN, K. (2008). Erasing the methyl mark: histone demethylases at the center of cellular differentiation and disease. Genes Dev 22: 1115-1140.

COUTURE, J.F., COLLAZO, E. and TRIEVEL, R.C. (2006). Molecular recognition of histone $\mathrm{H} 3$ by the WD40 protein WDR5. Nat Struct Mol Biol 13: 698-703.

DE NAPOLES, M., MERMOUD, J.E., WAKAO, R., TANG, Y.A., ENDOH, M., APPANAH, R., NESTEROVA, T.B., SILVA, J., OTTE, A.P., VIDAL, M. et al (2004). Polycomb group proteins Ring1A/B link ubiquitylation of histone $\mathrm{H} 2 \mathrm{~A}$ to heritable gene silencing and $X$ inactivation. Dev Cell 7: 663-676.

DE SANTA, F., TOTARO, M.G., PROSPERINI, E., NOTARBARTOLO, S., TESTA, G. and NATOLI, G. (2007). The histone H3 lysine-27 demethylase Jmjd3 links inflammation to inhibition of polycomb-mediated gene silencing. Cell130: 1083 1094.

DELLINO, G.I., SCHWARTZ, Y.B., FARKAS, G., MCCABE, D., ELGIN, S.C. and PIRROTTA, V. (2004). Polycomb silencing blocks transcription initiation. Mol Cell 13: 887-893.

DEMERS, C., CHATURVEDI, C.P., RANISH, J.A., JUBAN, G., LAI, P., MORLE, F., AEBERSOLD, R., DILWORTH, F.J., GROUDINE, M. and BRAND, M. (2007). Activator-mediated recruitment of the MLL2 methyltransferase complex to the beta-globin locus. Mol Cell 27: 573-584.

DOU, Y., MILNE, T.A., RUTHENBURG, A.J., LEE, S., LEE, J.W., VERDINE, G.L., ALLIS, C.D. and ROEDER, R.G. (2006). Regulation of MLL1 H3K4 methyltransferase activity by its core components. Nat Struct Mol Biol 13: 713719.

DOU, Y., MILNE, T.A., TACKETT, A.J., SMITH, E.R., FUKUDA, A., WYSOCKA, J., ALLIS, C.D., CHAIT, B.T., HESS, J.L. and ROEDER, R.G. (2005). Physical association and coordinate function of the $\mathrm{H} 3 \mathrm{~K} 4$ methyltransferase MLL1 and the H4 K16 acetyltransferase MOF. Cell 121: 873-885.

DREIJERINK, K.M., MULDER, K.W., WINKLER, G.S., HOPPENER, J.W., LIPS, C.J. and TIMMERS, H.T. (2006). Menin links estrogen receptor activation to histone H3K4 trimethylation. Cancer Res 66: 4929-4935.

ELDERKIN, S., MAERTENS, G.N., ENDOH, M., MALLERY, D.L., MORRICE, N., KOSEKI, H., PETERS, G., BROCKDORFF, N. and HIOM, K. (2007). A phosphorylated form of Mel-18 targets the Ring1B histone $\mathrm{H} 2 \mathrm{~A}$ ubiquitin ligase to chromatin. Mol Cell 28: 107-120.

ENDOH, M., ENDO, T.A., ENDOH, T., FUJIMURA, Y., OHARA, O., TOYODA, T., OTTE, A.P., OKANO, M., BROCKDORFF, N., VIDAL, M. et al. (2008). Polycomb group proteins Ring1A/B are functionally linked to the core transcriptiona regulatory circuitry to maintain ES cell identity. Development 135: 1513-1524

ERFURTH, F.E., POPOVIC, R., GREMBECKA, J., CIERPICKI, T., THEISLER, C., XIA, Z.B., STUART, T., DIAZ, M.O., BUSHWELLER, J.H. and ZELEZNIK-LE, N.J. (2008). MLL protects CpG clusters from methylation within the Hoxa9 gene, maintaining transcript expression. Proc Natl Acad Sci USA 105: 7517-7522.

ERNST, P., WANG, J., HUANG, M., GOODMAN, R.H. and KORSMEYER, S.J. (2001). MLL and CREB bind cooperatively to the nuclear coactivator CREBbinding protein. Mol Cell Biol 21: 2249-2258.

EVANS, R.M. (1988). The steroid and thyroid hormone receptor superfamily. Science 240: 889-95

EVANS, R.M. (2005). The nuclear receptor superfamily: a rosetta stone for physiology. Mol Endocrinol 19: 1429-1438.

FANG, S., MIAO, J., XIANG, L., PONUGOTI, B., TREUTER, E. and KEMPER, J.K. (2007). Coordinated recruitment of histone methyltransferase G9a and other chromatin-modifying enzymes in SHP-mediated regulation of hepatic bile acid metabolism. Mol Cell Biol 27: 1407-1424.

FICZ, G., HEINTZMANN, R. and ARNDT-JOVIN, D.J. (2005). Polycomb group protein complexes exchange rapidly in living Drosophila. Development 132 3963-3976.

FISCHLE, W., WANG, Y., JACOBS, S.A., KIM, Y., ALLIS, C.D. and KHORASANIZADEH, S. (2003). Molecular basis for the discrimination of repressive methyl-lysine marks in histone $\mathrm{H} 3$ by Polycomb and HP1 chromodomains. Genes Dev 17: 1870-1881.

GARCIA-BASSETS, I., KWON, Y.S., TELESE, F., PREFONTAINE, G.G., HUTT, 
K.R., CHENG, C.S., JU, B.G., OHGI, K.A., WANG, J., ESCOUBET-LOZACH, L. et al. (2007). Histone methylation-dependent mechanisms impose ligand dependency for gene activation by nuclear receptors. Cell 128: 505-518.

GARCIA, E., MARCOS-GUTIERREZ, C., DEL MARLORENTE, M., MORENO, J.C. and VIDAL, M. (1999). RYBP, a new repressor protein that interacts with components of the mammalian Polycomb complex, and with the transcription factor YY1. EMBO J 18: 3404-3418.

GLASER, S., SCHAFT, J., LUBITZ, S., VINTERSTEN, K., VAN DER HOEVEN, F., TUFTELAND, K.R., AASLAND, R., ANASTASSIADIS, K., ANG, S.L. and STEWART, A.F. (2006). Multiple epigenetic maintenance factors implicated by the loss of MII2 in mouse development. Development 133: 1423-1432.

GRAY, S.G., IGLESIAS, A.H., LIZCANO, F., VILLANUEVA, R., CAMELO, S., JINGU, H., TEH, B.T., KOIBUCHI, N., CHIN, W.W., KOKKOTOU, E. et al. (2005). Functional characterization of JMJD2A, a histone deacetylase- and retinoblastoma-binding protein. J Biol Chem 280: 28507-28518.

GUENTHER, M.G., JENNER, R.G., CHEVALIER, B., NAKAMURA, T., CROCE, C.M., CANAANI, E. and YOUNG, R.A. (2005). Global and Hox-specific roles for the MLL1 methyltransferase. Proc Natl Acad Sci USA 102: 8603-8608.

GUENTHER, M.G., LEVINE, S.S., BOYER, L.A., JAENISCH, R. and YOUNG, R.A. (2007). A chromatin landmark and transcription initiation at most promoters in human cells. Cell 130: 77-88.

HAN, Z., GUO, L., WANG, H., SHEN, Y., DENG, X.W. and CHAI, J. (2006). Structural basis for the specific recognition of methylated histone $\mathrm{H} 3$ lysine 4 by the WD-40 protein WDR5. Mol Cell 22: 137-144.

HESS, J.L. (2004). MLL: a histone methyltransferase disrupted in leukemia. Trends Mol Med 10: 500-507.

HOCK, R., FURUSAWA, T., UEDA, T. and BUSTIN, M. (2007). HMG chromosomal proteins in development and disease. Trends Cell Biol 17: 72-79.

HOUSTON, S.I., MCMANUS, K.J., ADAMS, M.M., SIMS, J.K., CARPENTER, P.B., HENDZEL, M.J. and RICE, J.C. (2008). Catalytic function of the PR-Set7 histone $\mathrm{H} 4$ lysine 20 monomethyltransferase is essential for mitotic entry and genomic stability. J Biol Chem. 283: 19478-19488.

HSIEH, J.J., CHENG, E.H. and KORSMEYER, S.J. (2003a). Taspase1: a threonine aspartase required for cleavage of MLL and proper HOX gene expression. Cell 115: 293-303.

HSIEH, J.J., ERNST, P., ERDJUMENT-BROMAGE, H., TEMPST, P. and KORSMEYER, S.J. (2003b). Proteolytic cleavage of MLL generates a complex of $\mathrm{N}$ - and $\mathrm{C}$-terminal fragments that confers protein stability and subnuclear localization. Mol Cell Biol 23: 186-194.

HUANG, J. and BERGER, S.L. (2008). The emerging field of dynamic lysine methylation of non-histone proteins. Curr Opin Genet Dev. 18: 152-158.

HUANG, N., VOM BAUR, E., GARNIER, J.M., LEROUGE, T., VONESCH, J.L., LUTZ, Y., CHAMBON, P. and LOSSON, R. (1998). Two distinct nuclear receptor interaction domains in NSD1, a novel SET protein that exhibits characteristics of both corepressors and coactivators. EMBO J 17: 3398-3412.

HUEN, M.S., SY, S.M., VAN DEURSEN, J.M. and CHEN, J. (2008). Direct interaction between SET8 and PCNA couples H4-K20 methylation with DNA replication. J Biol Chem. 283: 11073-11077.

HUQ, M.D., TSAI, N.P., KHAN, S.A. and WEI, L.N. (2007). Lysine trimethylation of retinoic acid receptor-alpha: a novel means to regulate receptor function. $\mathrm{Mol}$ Cell Proteomics 6: 677-688.

ISSAEVA, I., ZONIS, Y., ROZOVSKAIA, T., ORLOVSKY, K., CROCE, C.M., NAKAMURA, T., MAZO, A., EISENBACH, L. and CANAANI, E. (2007). Knockdown of ALR (MLL2) reveals ALR target genes and leads to alterations in cell adhesion and growth. Mol Cell Biol 27: 1889-1903.

JACOBS, J.J., KIEBOOM, K., MARINO, S., DEPINHO, R.A. and VAN LOHUIZEN, M. (1999). The oncogene and Polycomb-group gene bmi- 1 regulates cell proliferation and senescence through the ink4a locus. Nature 397: 164-168.

JEPSEN, K., SOLUM, D., ZHOU, T., MCEVILLY, R.J., KIM, H.J., GLASS, C.K., HERMANSON, O. and ROSENFELD, M.G. (2007). SMRT-mediated repression of an H3K27 demethylase in progression from neural stem cell to neuron. Nature 450: 415-419.

JOO, H.Y., ZHAI, L., YANG, C., NIE, S., ERDJUMENT-BROMAGE, H., TEMPST, P., CHANG, C. and WANG, H. (2007). Regulation of cell cycle progression and gene expression by H2A deubiquitination. Nature 449: 1068-1072.

JORGENSEN, S., ELVERS, I., TRELLE, M.B., MENZEL, T., ESKILDSEN, M.,
JENSEN, O.N., HELLEDAY, T., HELIN, K. and SORENSEN, C.S. (2007). The histone methyltransferase SET8 is required for S-phase progression. $\mathrm{J} \mathrm{Cell} \mathrm{Biol}$ 179: 1337-1345.

JULIEN, E. and HERR, W. (2004). A switch in mitotic histone H4 lysine 20 methylation status is linked to M phase defects upon loss of HCF-1. Mol Cell 14: 713-725.

KAHL, P., GULLOTTI, L., HEUKAMP, L.C., WOLF, S., FRIEDRICHS, N., VORREUTHER, R., SOLLEDER, G., BASTIAN, P.J., ELLINGER, J., METZGER, E. et al. (2006). Androgen receptor coactivators lysine-specific histone demethylase 1 and four and a half LIM domain protein 2 predict risk of prostate cancer recurrence. Cancer Res 66: 11341-11347.

KARACHENTSEV, D., DRUZHININA, M. and STEWARD, R. (2007). Free and chromatin-associated mono-, di-, and trimethylation of histone H4-lysine 20 during development and cell cycle progression. Dev Biol 304: 46-52.

KARACHENTSEV, D., SARMA, K., REINBERG, D. and STEWARD, R. (2005). PRSet7-dependent methylation of histone $\mathrm{H} 4$ Lys 20 functions in repression of gene expression and is essential for mitosis. Genes Dev 19: 431-435.

KING, I.F., FRANCIS, N.J. and KINGSTON, R.E. (2002). Native and recombinant polycomb group complexes establish a selective block to template accessibility to repress transcription in vitro. Mol Cell Biol 22: 7919-7928.

KLOSE, R.J., YAN, Q., TOTHOVA, Z., YAMANE, K., ERDJUMENT-BROMAGE, H., TEMPST, P., GILLILAND, D.G., ZHANG, Y. and KAELIN, W.G., JR. (2007). The retinoblastoma binding protein RBP2 is an H3K4 demethylase. Cell 128: 889900.

KOTAKE, Y., CAO, R., VIATOUR, P., SAGE, J., ZHANG, Y. and XIONG, Y. (2007). pRB family proteins are required for H3K27 trimethylation and Polycomb repression complexes binding to and silencing p16INK4alpha tumor suppressor gene. Genes Dev 21: 49-54.

KUZMICHEV, A., JENUWEIN, T., TEMPST, P. and REINBERG, D. (2004). Different EZH2-containing complexes target methylation of histone $\mathrm{H} 1$ or nucleosomal histone H3. Mol Cell 14: 183-193.

KUZMICHEV, A., MARGUERON, R., VAQUERO, A., PREISSNER, T.S., SCHER, M., KIRMIZIS, A., OUYANG, X., BROCKDORFF, N., ABATE-SHEN, C., FARNHAM, P. et al. (2005). Composition and histone substrates of polycomb repressive group complexes change during cellular differentiation. Proc Natl Acad Sci USA 102: 1859-1864.

LAGAROU, A., MOHD SARIP, A., MOSHKIN, Y.M., CHALKLEY, G.E., BEZSTAROSTI, K., DEMMERS, J.A. and VERRIJZER, C.P. (2008). dKDM2 couples histone $\mathrm{H} 2 \mathrm{~A}$ ubiquitylation to histone $\mathrm{H} 3$ demethylation during Polycomb group silencing. Genes Dev. 15: 27992810.

LAN, F., BAYLISS, P.E., RINN, J.L., WHETSTINE, J.R., WANG, J.K., CHEN, S., IWASE, S., ALPATOV, R., ISSAEVA, I., CANAANI, E. et al. (2007). A histone $\mathrm{H} 3$ lysine 27 demethylase regulates animal posterior development. Nature 449: 689-694.

LEE, D.Y., NORTHROP, J.P., KUO, M.H. and STALLCUP, M.R. (2006a). Histone H3 lysine 9 methyltransferase G9a is a transcriptional coactivator for nuclear receptors. J Biol Chem 281: 8476-8485.

LEE, J.H. and SKALNIK, D.G. (2005). CpG-binding protein (CXXC finger protein 1) is a component of the mammalian Set1 histone H3-Lys4 methyltransferase complex, the analogue of the yeast Set1/COMPASS complex. J Biol Chem 280: 41725-41731.

LEE, J.H. and SKALNIK, D.G. (2008). Wdr82 is a C-terminal domain-binding protein that recruits the Setd1A Histone H3-Lys4 methyltransferase complex to transcription start sites of transcribed human genes. Mol Cell Biol 28: 609-618.

LEE, J.H., TATE, C.M., YOU, J.S. and SKALNIK, D.G. (2007a). Identification and characterization of the human Set1B histone H3-Lys4 methyltransferase complex. J Biol Chem 282: 13419-13428.

LEE, M.G., NORMAN, J., SHILATIFARD, A. and SHIEKHATTAR, R. (2007b). Physical and functional association of a trimethyl H3K4 demethylase and Ring6a/MBLR, a polycomb-like protein. Cell 128: 877-887.

LEE, M.G., VILLA, R., TROJER, P., NORMAN, J., YAN, K.P., REINBERG, D., DI CROCE, L. and SHIEKHATTAR, R. (2007C). Demethylation of H3K27 regulates polycomb recruitment and H2A ubiquitination. Science 318: 447-450.

LEE, T.I., JENNER, R.G., BOYER, L.A., GUENTHER, M.G., LEVINE, S.S., KUMAR, R.M., CHEVALIER, B., JOHNSTONE, S.E., COLE, M.F., ISONO, K. et al. (2006b). Control of developmental regulators by Polycomb in human embryonic 
stem cells. Cell 125: 301-313.

LEEB, M. and WUTZ, A. (2007). Ring1B is crucial for the regulation of developmental control genes and $\mathrm{PRC} 1$ proteins but not $\mathrm{X}$ inactivation in embryonic cells. $J$ Cell Biol 178: 219-229.

LEVINE, S.S., WEISS, A., ERDJUMENT-BROMAGE, H., SHAO, Z., TEMPST, P. and KINGSTON, R.E. (2002). The core of the polycomb repressive complex is compositionally and functionally conserved in flies and humans. Mol Cell Biol 22: 6070-6078.

LEWIS, A., MITSUYA, K., UMLAUF, D., SMITH, P., DEAN, W., WALTER, J., HIGGINS, M., FEIL, R. and REIK, W. (2004). Imprinting on distal chromosome 7 in the placenta involves repressive histone methylation independent of DNA methylation. Nat Genet 36: 1291-1295.

LI, H., ILIN, S., WANG, W., DUNCAN, E.M., WYSOCKA, J., ALLIS, C.D. and PATEL, D.J. (2006). Molecular basis for site-specific read-out of histone H3K4me3 by the BPTF PHD finger of NURF. Nature 442: 91-95.

LUBITZ, S., GLASER, S., SCHAFT, J., STEWART, A.F. and ANASTASSIADIS, K. (2007). Increased apoptosis and skewed differentiation in mouse embryonic stem cells lacking the histone methyltransferase MII2. Mol Biol Cell 18: 23562366.

MAGER, J., MONTGOMERY, N.D., DE VILLENA, F.P. and MAGNUSON, T. (2003). Genome imprinting regulated by the mouse Polycomb group protein Eed. Nat Genet 33: 502-507.

MARTIN, C. and ZHANG, Y. (2005). The diverse functions of histone lysine methylation. Nat Rev Mol Cell Biol 6: 838-849.

MASSIE, C.E., ADRYAN, B., BARBOSA-MORAIS, N.L., LYNCH, A.G., TRAN, M.G., NEAL, D.E. and MILLS, I.G. (2007). New androgen receptor genomic targets show an interaction with the ETS1 transcription factor. EMBO Rep 8: 871-878.

MCMANUS, K.J., BIRON, V.L., HEIT, R., UNDERHILL, D.A. and HENDZEL, M.J. (2006). Dynamic changes in histone $\mathrm{H} 3$ lysine 9 methylations: identification of a mitosis-specific function for dynamic methylation in chromosome congression and segregation. $J$ Biol Chem 281: 8888-8897.

METIVIER, R., PENOT, G., HUBNER, M.R., REID, G., BRAND, H., KOS, M. and GANNON, F. (2003). Estrogen receptor-alpha directs ordered, cyclical, and combinatorial recruitment of cofactors on a natural target promoter. Cell 115: 751-763.

METZGER, E., WISSMANN, M., YIN, N., MULLER, J.M., SCHNEIDER, R., PETERS, A.H., GUNTHER, T., BUETTNER, R. and SCHULE, R. (2005). LSD1 demethylates repressive histone marks to promote androgen-receptor-dependent transcription. Nature 437: 436-439.

METZGER, E., YIN, N., WISSMANN, M., KUNOWSKA, N., FISCHER, K., FRIEDRICHS, N., PATNAIK, D., HIGGINS, J.M., POTIER, N., SCHEIDTMANN K.H. et al. (2008). Phosphorylation of histone $\mathrm{H} 3$ at threonine 11 establishes a novel chromatin mark for transcriptional regulation. Nat Cell Biol 10: 53-60.

MIKKELSEN, T.S., KU, M., JAFFE, D.B., ISSAC, B., LIEBERMAN, E., GIANNOUKOS, G., ALVAREZ, P., BROCKMAN, W., KIM, T.K., KOCHE, R.P. et al. (2007). Genome-wide maps of chromatin state in pluripotent and lineagecommitted cells. Nature 448: 553-560.

MILNE, T.A., DOU, Y., MARTIN, M.E., BROCK, H.W., ROEDER, R.G. and HESS, J.L. (2005a). MLL associates specifically with a subset of transcriptionally active target genes. Proc Natl Acad Sci USA 102: 14765-14770.

MILNE, T.A., HUGHES, C.M., LLOYD, R., YANG, Z., ROZENBLATT-ROSEN, O., DOU, Y., SCHNEPP, R.W., KRANKEL, C., LIVOLSI, V.A., GIBBS, D. et al. (2005b). Menin and MLL cooperatively regulate expression of cyclin-dependent kinase inhibitors. Proc Natl Acad Sci USA 102: 749-754.

MIN, J., ZHANG, Y. and XU, R.M. (2003). Structural basis for specific binding of Polycomb chromodomain to histone H3 methylated at Lys 27. Genes Dev 17: 1823-1828.

MO, R., RAO, S.M. and ZHU, Y.J. (2006). Identification of the MLL2 complex as a coactivator for estrogen receptor alpha. J Biol Chem 281: 15714-15720.

MOHN, F., WEBER, M., REBHAN, M., ROLOFF, T.C., RICHTER, J., STADLER, M.B., BIBEL, M. and SCHUBELER, D. (2008). Lineage-Specific Polycomb Targets and De Novo DNA Methylation Define Restriction and Potential of Neuronal Progenitors. Mol Cell 30: 755-766.

MONTGOMERY, N.D., YEE, D., CHEN, A., KALANTRY, S., CHAMBERLAIN, S.J., OTTE, A.P. and MAGNUSON, T. (2005). The murine polycomb group protein
Eed is required for global histone H3 lysine-27 methylation. Curr Biol 15: 942947.

MOSTAQUL HUQ, M.D., GUPTA, P., TSAI, N.P., WHITE, R., PARKER, M.G. and WEI, L.N. (2006). Suppression of receptor interacting protein 140 repressive activity by protein arginine methylation. EMBO J 25: 5094-5104.

NAKAGAWA, T., KAJITANI, T., TOGO, S., MASUKO, N., OHDAN, H., HISHIKAWA Y., KOJI, T., MATSUYAMA, T., IKURA, T., MURAMATSU, M. et al. (2008) Deubiquitylation of histone $\mathrm{H} 2 \mathrm{~A}$ activates transcriptional initiation via transhistone cross-talk with H3K4 di- and trimethylation. Genes Dev 22: 37-49.

NAKAMURA, T., MORI, T., TADA, S., KRAJEWSKI, W., ROZOVSKAIA, T., WASSELL, R., DUBOIS, G., MAZO, A., CROCE, C.M. and CANAANI, E. (2002). ALL-1 is a histone methyltransferase that assembles a supercomplex of proteins involved in transcriptional regulation. Mol Cell 10: 1119-1128.

NARAYANAN, A., RUYECHAN, W.T. and KRISTIE, T.M. (2007). The coactivator host cell factor-1 mediates Set1 and MLL1 H3K4 trimethylation at herpesvirus immediate early promoters for initiation of infection. Proc Natl Acad Sci USA 104: 10835-10840.

NARITA, M., NUNEZ, S., HEARD, E., LIN, A.W., HEARN, S.A., SPECTOR, D.L., HANNON, G.J. and LOWE, S.W. (2003). Rb-mediated heterochromatin formation and silencing of E2F target genes during cellular senescence. Cell 113: 703-716.

NICASSIO, F., CORRADO, N., VISSERS, J.H., ARECES, L.B., BERGINK, S. MARTEIJN, J.A., GEVERTS, B., HOUTSMULLER, A.B., VERMEULEN, W., DI FIORE, P.P. et al. (2007). Human USP3 is a chromatin modifier required for $S$ phase progression and genome stability. Curr Biol 17: 1972-1977.

NIELSEN, S.J., SCHNEIDER, R., BAUER, U.M., BANNISTER, A.J., MORRISON A., O'CARROLL, D., FIRESTEIN, R., CLEARY, M., JENUWEIN, T., HERRERA, R.E. et al. (2001). Rb targets histone $\mathrm{H} 3$ methylation and HP1 to promoters. Nature 412: 561-565

NISHIOKA, K., RICE, J.C., SARMA, K., ERDJUMENT-BROMAGE, H., WERNER J., WANG, Y., CHUIKOV, S., VALENZUELA, P., TEMPST, P., STEWARD, R et al. (2002). PR-Set7 is a nucleosome-specific methyltransferase that modifies lysine 20 of histone $\mathrm{H} 4$ and is associated with silent chromatin. Mol Cell9: 1201 1213.

NOBREGA, M.A., OVCHARENKO, I., AFZAL, V. and RUBIN, E.M. (2003). Scanning human gene deserts for long-range enhancers. Science 302: 413.

ODA, H., OKAMOTO, I., MURPHY, N., CHU, J., PRICE, S.M., SHEN, M.M. TORRES-PADILLA, M.E., HEARD, E. and REINBERG, D. (2009). Monomethylation of histone $\mathrm{H} 4$ lysine 20 is involved in chromosome structure and stability and is essential for mouse development. Mol Cell Biol 29: 2278 2295.

OGAWA, H., ISHIGURO, K., GAUBATZ, S., LIVINGSTON, D.M. and NAKATANI, $Y$. (2002). A complex with chromatin modifiers that occupies E2F- and Mycresponsive genes in G0 cells. Science 296: 1132-1136.

ORFORD, K., KHARCHENKO, P., LAI, W., DAO, M.C., WORHUNSKY, D.J., FERRO, A., JANZEN, V., PARK, P.J. and SCADDEN, D.T. (2008). Differential H3K4 methylation identifies developmentally poised hematopoietic genes. Dev Cell 14: 798-809.

OTTE, A.P. and KWAKS, T.H. (2003). Gene repression by Polycomb group protein complexes: a distinct complex for every occasion? Curr Opin Genet Dev 13: 448-454.

PAN, G., TIAN, S., NIE, J., YANG, C., RUOTTI, V., WEI, H., JONSDOTTIR, G.A. STEWART, R. and THOMSON, J.A. (2007). Whole-genome analysis of histone $\mathrm{H} 3$ lysine 4 and lysine 27 methylation in human embryonic stem cells. Cell Stem Cell 1: 299-312.

PANFEY, R.R., MONDAL, T., MOHAMMAD, F., ENROTH, S., REDRUP, L., KOMOROWSKI, J., NAGANO, T., MANCINI DINARDO, D. and KANDURLI, C. (2008). Kcnq1ot1 antisense noncoding RNA mediates lineage specific transcriptional silencing through chromatin level regulation. Mol Cell 32: 232 246.

PASINI, D., BRACKEN, A.P., JENSEN, M.R., LAZZERINI DENCHI, E. and HELIN, K. (2004). Suz12 is essential for mouse development and for EZH2 histone methyltransferase activity. EMBO J 23: 4061-4071.

PASINI, D., HANSEN, K.H., CHRISTENSEN, J., AGGER, K., CLOOS, P.A. and HELIN, K. (2008). Coordinated regulation of transcriptional repression by the RBP2 H3K4 demethylase and Polycomb-Repressive Complex 2. Genes Dev 22: $1345-1355$. 
PATEL, S.R., KIM, D., LEVITAN, I. and DRESSLER, G.R. (2007). The BRCTdomain containing protein PTIP links PAX2 to a histone $\mathrm{H} 3$, lysine 4 methyltransferase complex. Dev Cell 13: 580-592.

PERILlO, B., OMBRA, M.N., BERTONI, A., CUOZZO, C., SACCHETTI, S., SASSO, A., CHIARIOTTI, L., MALORNI, A., ABBONDANZA, C. and AVVEDIMENTO, E.V. (2008). DNA oxidation as triggered by H3K9me2 demethylation drives estrogen-induced gene expression. Science 319: 202206.

PERISSI, V. and ROSENFELD, M.G. (2005). Controlling nuclear receptors: the circular logic of cofactor cycles. Nat Rev Mol Cell Biol 6: 542-554.

PESAVENTO, J.J., BULLOCK, C.R., LEDUC, R.D., MIZZEN, C.A. and KELLEHER, N.L. (2008a). Combinatorial Modification of Human Histone H4 Quantitated by Two-dimensional Liquid Chromatography Coupled with Top Down Mass Spectrometry. J Biol Chem 283: 14927-14937.

PESAVENTO, J.J., YANG, H., KELLEHER, N.L. and MIZZEN, C.A. (2008b). Certain and progressive methylation of histone $\mathrm{H} 4$ at lysine 20 during the cell cycle. Mol Cell Biol 28: 468-486.

PLANAS-SILVA, M.D. and WEINBERG, R.A. (1997). The restriction point and control of cell proliferation. Curr Opin Cell Biol 9: 768-772.

PUSCHENDORF, M., TERRANOVA, R., BOUTSMA, E., MAO, X., ISONO, K., BRYKCZYNSKA, U., KOLB, C., OTTE, A.P., KOSEKI, H., ORKIN, S.H. et al. (2008). PRC1 and Suv39h specify parental asymmetry at constitutive heterochromatin in early mouse embryos. Nat Genet 40: 411-420.

RAYASAM, G.V., WENDLING, O., ANGRAND, P.O., MARK, M., NIEDERREITHER, K., SONG, L., LEROUGE, T., HAGER, G.L., CHAMBON, P. and LOSSON, R. (2003). NSD1 is essential for early post-implantation development and has a catalytically active SET domain. EMBO J 22: 3153-3163.

REN, X., VINCENZ, C. and KERPPOLA, T.K. (2008). Changes in the distributions and dynamics of polycomb repressive complexes during embryonic stem cell differentiation. Mol Cell Biol 28: 2884-2895.

RICE, J.C., NISHIOKA, K., SARMA, K., STEWARD, R., REINBERG, D. and ALLIS, C.D. (2002). Mitotic-specific methylation of histone H4 Lys 20 follows increased PR-Set7 expression and its localization to mitotic chromosomes. Genes Dev16: 2225-2230.

RINGROSE, L. and PARO, R. (2004). Epigenetic regulation of cellular memory by the Polycomb and Trithorax group proteins. Annu Rev Genet 38: 413-443.

RINN, J.L., KERTESZ, M., WANG, J.K., SQUAZZO, S.L., XU, X., BRUGMANN, S.A., GOODNOUGH, L.H., HELMS, J.A., FARNHAM, P.J., SEGAL, E. et al. (2007). Functional demarcation of active and silent chromatin domains in human HOX loci by noncoding RNAs. Cell 129: 1311-1323.

ROSENFELD, M.G. and GLASS, C.K. (2001). Coregulator codes of transcriptional regulation by nuclear receptors. J Biol Chem 276: 36865-36868.

RUTHENBURG, A.J., ALLIS, C.D. and WYSOCKA, J. (2007). Methylation of lysine 4 on histone $\mathrm{H} 3$ : intricacy of writing and reading a single epigenetic mark. $\mathrm{Mol}$ Cell 25: 15-30.

RUthenBurg, A.J., WANG, W., GRAYBOSCH, D.M., LI, H., ALLIS, C.D., PATEL, D.J. and VERDINE, G.L. (2006). Histone H3 recognition and presentation by the WDR5 module of the MLL1 complex. Nat Struct Mol Biol 13: 704-712.

SAKAGUCHI, A. and STEWARD, R. (2007). Aberrant monomethylation of histone H4 lysine 20 activates the DNA damage checkpoint in Drosophila melanogaster. J Cell Biol 176: 155-162.

SAXONOV, S., BERG, P. and BRUTLAG, D.L. (2006). A genome-wide analysis of $\mathrm{CpG}$ dinucleotides in the human genome distinguishes two distinct classes of promoters. Proc Natl Acad Sci USA 103: 1412-1417.

SCHARF, A.N., MEIER, K., SEITZ, V., KREMMER, E., BREHM, A. and IMHOF, A. (2009). Monomethylation of lysine 20 on histone $\mathrm{H} 4$ facilitates chromatin maturation. Mol Cell Biol. 29: 57-67.

SCHOEFTNER, S., SENGUPTA, A.K., KUBICEK, S., MECHTLER, K., SPAHN, L., KOSEKI, H., JENUWEIN, T. and WUTZ, A. (2006). Recruitment of PRC1 function at the initiation of $X$ inactivation independent of PRC2 and silencing. EMBO J 25: 3110-3122.

SCHOTTA, G., LACHNER, M., SARMA, K., EBERT, A., SENGUPTA, R., REUTER, G., REINBERG, D. and JENUWEIN, T. (2004). A silencing pathway to induce $\mathrm{H} 3-\mathrm{K} 9$ and H4-K20 trimethylation at constitutive heterochromatin. Genes Dev 18: $1251-1262$.

SCHUETZ, A., ALlali-hassani, A., MARTIN, F., LOPPNAU, P., VEDADI, M.,
BOCHKAREV, A., PLOTNIKOV, A.N., ARROWSMITH, C.H. and MIN, J. (2006). Structural basis for molecular recognition and presentation of histone $\mathrm{H} 3$ by WDR5. EMBO J 25: 4245-4252.

SCHULTE, J.H., LIM, S., SCHRAMM, A., FRIEDRICHS, N., KOSTER, J. VERSTEEG, R, ORA, I., PAITLER, K., KLEIN HITPASS, L., KUHFITTIG KULLE, S., METZGER, E., SCHUELE, R., EGGERT, A, BUETTNER, R. and KIRFEL, J. (2009). Lysine specific demethylase 1 is strongly expressed in poorly differentiated neuroblastoma: implications for therapy. Cancer Res. 69: 206571.

SCHWARTZ, Y.B. and PIRROTTA, V. (2007). Polycomb silencing mechanisms and the management of genomic programmes. Nat Rev Genet 8: 9-22.

SCIBETTA, A.G., SANTANGELO, S., COLEMAN, J., HALL, D., CHAPLIN, T., COPIER, J., CATCHPOLE, S., BURCHELL, J. and TAYLOR-PAPADIMITRIOU, J. (2007). Functional analysis of the transcription repressor PLU-1/JARID1B. Mol Cell Biol 27: 7220-7235.

SEDKOV, Y., CHO, E., PETRUK, S., CHERBAS, L., SMITH, S.T., JONES, R.S., CHERBAS, P., CANAANI, E., JAYNES, J.B. and MAZO, A. (2003). Methylation at lysine 4 of histone $\mathrm{H} 3$ in ecdysone-dependent development of Drosophila. Nature 426: 78-83.

SHAO, Z., RAIBLE, F., MOLLAAGHABABA, R., GUYON, J.R., WU, C.T., BENDER, W. and KINGSTON, R.E. (1999). Stabilization of chromatin structure by PRC1, a Polycomb complex. Cell 98: 37-46.

SHEN, J.C., RIDEOUT, W.M., 3RD and JONES, P.A. (1994). The rate of hydrolytic deamination of 5-methylcytosine in double-stranded DNA. Nucleic Acids Res 22: 972-976.

SHI, X., KACHIRSKAIA, I., YAMAGUCHI, H., WEST, L.E., WEN, H., WANG, E.W., DUTTA, S., APPELLA, E. and GOZANI, O. (2007). Modulation of p53 function by SET8-mediated methylation at lysine 382. Mol Cell 27: 636-646.

SHIN, S. and JANKNECHT, R. (2007a). Activation of androgen receptor by histone demethylases JMJD2A and JMJD2D. Biochem Biophys Res Commun 359: 742-746.

SHIN, S. and JANKNECHT, R. (2007b). Diversity within the JMJD2 histone demethylase family. Biochem Biophys Res Commun 353: 973-977.

SIMONS, C., PHEASANT, M., MAKUNIN, I.V. and MATTICK, J.S. (2006). Transposon-free regions in mammalian genomes. Genome Res 16: 164-172.

SMITH, E.R., LEE, M.G., WINTER, B., DROZ, N.M., EISSENBERG, J.C., SHIEKHATTAR, R. and SHILATIFARD, A. (2008). Drosophila UTX is a histone H3 Lys27 demethylase that colocalizes with the elongating form of RNA polymerase II. Mol Cell Biol 28: 1041-1046.

STEWARD, M.M., LEE, J.S., O'DONOVAN, A., WYATT, M., BERNSTEIN, B.E. and SHILATIFARD, A. (2006). Molecular regulation of H3K4 trimethylation by ASH2L, a shared subunit of MLL complexes. Nat Struct Mol Biol 13: 852-854.

STOCK, J.K., GIADROSSI, S., CASANOVA, M., BROOKES, E., VIDAL, M., KOSEKI, H., BROCKDORFF, N., FISHER, A.G. and POMBO, A. (2007). Ring1mediated ubiquitination of $\mathrm{H} 2 \mathrm{~A}$ restrains poised RNA polymerase II at bivalent genes in mouse ES cells. Nat Cell Biol 9: 1428-1435.

SUBRAMANIAN, K., JIA, D., KAPOOR-VAZIRANI, P., POWELL, D.R., COLLINS, R.E., SHARMA, D., PENG, J., CHENG, X. and VERTINO, P.M. (2008). Regulation of estrogen receptor alpha by the SET7 lysine methyltransferase. Mol Cell 30: 336-347.

TANAY, A., O'DONNELL, A.H., DAMELIN, M. and BESTOR, T.H. (2007). Hyperconserved $\mathrm{CpG}$ domains underlie Polycomb-binding sites. Proc Natl Acad Sci USA 104: 5521-5526.

TARDAT, M., MURR, R., HERCEG, Z., SARDET, C. and JULIEN, E. (2007). PRSet7-dependent lysine methylation ensures genome replication and stability through S phase. J Cell Biol 179: 1413-1426.

TERRANOVA, R., YOKOBAYASHI, S., STADLER, M., OTTE, A.P., VAN LOHUIZEN, M., ORKIN, S.H., and PETERS, A.H.F.M. (2008). Polycomb-group proteins Ezh2 and Rnf2 direct genomic contraction and imprinted repression in early mouse embryos. Dev. Cell 15: 668-679.

TYAGI, S., CHABES, A.L., WYSOCKA, J. and HERR, W. (2007). E2F activation of $S$ phase promoters via association with HCF-1 and the MLL family of histone H3K4 methyltransferases. Mol Cell 27: 107-119.

UMLAUF, D., GOTO, Y., CAO, R., CERQUEIRA, F., WAGSCHAL, A., ZHANG, Y. and FEIL, R. (2004). Imprinting along the Kenq1 domain on mouse chromosome 7 involves repressive histone methylation and recruitment of Polycomb group 
complexes. Nat Genet 36: 1296-1300.

VALLS, E., SANCHEZ-MOLINA, S. and MARTINEZ-BALBAS, M.A. (2005). Role of histone modifications in marking and activating genes through mitosis. $J$ Biol Chem 280: 42592-42600.

VAN DER STOOP, P., BOUTSMA, E.A., HULSMAN, D., NOBACK, S., HEIMERIKX, M., KERKHOVEN, R.M., VONCKEN, J.W., WESSELS, L.F. and VANLOHUIZEN, M. (2008). Ubiquitin E3 ligase Ring1b/Rnf2 of polycomb repressive complex 1 contributes to stable maintenance of mouse embryonic stem cells. PLOS ONE 3: e2235.

VOO, K.S., CARLONE, D.L., JACOBSEN, B.M., FLODIN, A. and SKALNIK, D.G. (2000). Cloning of a mammalian transcriptional activator that binds unmethylated CpG motifs and shares a CXXC domain with DNA methyltransferase, human trithorax, and methyl-CpG binding domain protein 1. Mol Cell Biol 20: 21082121.

WANG, H., WANG, L., ERDJUMENT-BROMAGE, H., VIDAL, M., TEMPST, P., JONES, R.S. and ZHANG, Y. (2004a). Role of histone H2A ubiquitination in Polycomb silencing. Nature 431: 873-878.

WANG, L., BROWN, J.L., CAO, R., ZHANG, Y., KASSIS, J.A. and JONES, R.S. (2004b). Hierarchical recruitment of polycomb group silencing complexes. Mol Cell 14: 637-646.

WEBER, M., HELLMANN, I., STADLER, M.B., RAMOS, L., PAABO, S., REBHAN, M. and SCHUBELER, D. (2007). Distribution, silencing potential and evolutionary impact of promoter DNA methylation in the human genome. Nat Genet 39: 457-466.

WEI, Y., YU, L., BOWEN, J., GOROVSKY, M.A. and ALLIS, C.D. (1999). Phosphorylation of histone $\mathrm{H} 3$ is required for proper chromosome condensation and segregation. Cell 97: 99-109.

WHITCOMB, S.J., BASU, A., ALLIS, C.D. and BERNSTEIN, E. (2007). Polycomb Group proteins: an evolutionary perspective. Trends Genet 23: 494-502.

WISSMANN, M., YIN, N., MULLER, J.M., GRESCHIK, H., FODOR, B.D., JENUWEIN, T., VOGLER, C., SCHNEIDER, R., GUNTHER, T., BUETTNER, R. et al. (2007). Cooperative demethylation by JMJD2C and LSD1 promotes androgen receptor-dependent gene expression. Nat Cell Biol 9: 347-353.

WOLF, S.S., PATCHEV, V.K. and OBENDORF, M. (2007). A novel variant of the putative demethylase gene, S-JMJD1C, is a coactivator of the AR. Arch Biochem Biophys 460: 56-66.

WYSOCKA, J., SWIGUT, T., XIAO, H., MILNE, T.A., KWON, S.Y., LANDRY, J., KAUER, M., TACKETT, A.J., CHAIT, B.T., BADENHORST, P. et al. (2006). A $\mathrm{PHD}$ finger of NURF couples histone $\mathrm{H} 3$ lysine 4 trimethylation with chromatin remodelling. Nature 442: 86-90.

XIA, Z.B., ANDERSON, M., DIAZ, M.O. and ZELEZNIK-LE, N.J. (2003). MLL repression domain interacts with histone deacetylases, the polycomb group proteins HPC2 and BMI-1, and the corepressor C-terminal-binding protein. Proc Natl Acad Sci USA 100: 8342-8347.

XIAO, B., JING, C., KELLY, G., WALKER, P.A., MUSKETT, F.W., FRENKIEL, T.A.,
MARTIN, S.R., SARMA, K., REINBERG, D., GAMBLIN, S.J. et al. (2005). Specificity and mechanism of the histone methyltransferase Pr-Set7. Genes Dev 19: 1444-1454.

XU, W., CHEN, H., DU, K., ASAHARA, H., TINI, M., EMERSON, B.M., MONTMINY, M. and EVANS, R.M. (2001). A transcriptional switch mediated by cofactor methylation. Science 294: 2507-2511.

XU, W., CHO, H., KADAM, S., BANAYO, E.M., ANDERSON, S., YATES, J.R., 3RD, EMERSON, B.M. and EVANS, R.M. (2004). A methylation-mediator complex in hormone signaling. Genes Dev 18: 144-156.

YAGI, H., DEGUCHI, K., AONO, A., TANI, Y., KISHIMOTO, T. and KOMORI, T. (1998). Growth disturbance in fetal liver hematopoiesis of Mll-mutant mice. Blood 92: 108-117.

YAMANE, K., TOUMAZOU, C., TSUKADA, Y., ERDJUMENT-BROMAGE, H., TEMPST, P., WONG, J. and ZHANG, Y. (2006). JHDM2A, a JmjC-containing H3K9 demethylase, facilitates transcription activation by androgen receptor. Cell 125: 483-495

YANG, H., PESAVENTO, J.J., STARNES, T.W., CRYDERMAN, D.E., WALLRATH, L.L., KELLEHER, N.L. and MIZZEN, C.A. (2008). Preferential dimethylation of histone H4-lysine 20 by Suv4-20. J Biol Chem. 283: 12085-12092.

YU, B.D., HANSON, R.D., HESS, J.L., HORNING, S.E. and KORSMEYER, S.J. (1998). MLL, a mammalian trithorax-group gene, functions as a transcriptional maintenance factor in morphogenesis. Proc Natl Acad Sci USA 95: 1063210636.

YU, B.D., HESS, J.L., HORNING, S.E., BROWN, G.A. and KORSMEYER, S.J. (1995). Altered Hox expression and segmental identity in Mll-mutant mice. Nature 378: 505-508.

ZHANG, H., CHRISTOFOROU, A., ARAVIND, L., EMMONS, S.W., VAN DEN HEUVEL, S. and HABER, D.A. (2004). The C. elegans Polycomb gene SOP-2 encodes an RNA binding protein. Mol Cell 14: 841-847.

ZHAO, X.D., HAN, X., CHEW, J.L., LIU, J., CHIU, K.P., CHOO, A., ORLOV, Y.L., SUNG, W.K., SHAHAB, A., KUZNETSOV, V.A. et al. (2007). Whole-genome mapping of histone $\mathrm{H} 3$ Lys 4 and 27 trimethylations reveals distinct genomic compartments in human embryonic stem cells. Cell Stem Cell 1: 286-298.

ZHAO, J., SUN, B.K., ERWIN, J.A., SONG, J. J. and LEE, J. T. (2008). Polycomb proteins targeted by a short repeat RNA to the mouse $X$ chromosome. Science 322: 750756 .

ZHOU, W., ZHU, P., WANG, J., PASCUAL, G., OHGI, K.A., LOZACH, J., GLASS, C.K. and ROSENFELD, M.G. (2008). Histone H2A monoubiquitination represses transcription by inhibiting RNA polymerase II transcriptional elongation. Mol Cell 29: 69-80.

ZHU, P., ZHOU, W., WANG, J., PUC, J., OHGI, K.A., ERDJUMENT-BROMAGE, H., TEMPST, P., GLASS, C.K. and ROSENFELD, M.G. (2007). A histone H2A deubiquitinase complex coordinating histone acetylation and $\mathrm{H} 1$ dissociation in transcriptional regulation. Mol Cell 27: 609-621. 


\section{Further Related Reading, published previously in the Int. J. Dev. Biol.}

See our Special Issue Fertilization edited by Paul M. Wassarman and Victor D. Vacquier at: http://www.ijdb.ehu.es/web/contents. php?vol=52\&issue=5-6

\section{Understanding the regulatory genome.}

M. Eva Alonso, Bárbara Pernaute, Miguel Crespo, José Luis Gomez Skarmeta and Miguel Manzanares.

Int. J. Dev. Biol. (2009) 53: doi: 10.1387/ijdb.072428ma

2006 ISI **Impact Factor $=3.577^{* *}$

Dynamic distribution of the replacement histone variant $\mathrm{H} 3.3$ in the mouse oocyte and preimplantation embryos.

Maria Elena Torres Padilla, Andrew J. Bannister, Paul J. Hurd, Tony Kouzarides and Magdalena Zernicka Goetz.

Int. J. Dev. Biol. (2006) 50: 455461

Control of reproduction by Polycomb Group complexes in animals and plants. Anne Elisabeth Guitton and Frederic Berger.

Int. J. Dev. Biol. (2005) 49: 707716

Histone methylation defines epigenetic asymmetry in the mouse zygote. Katharine L Arney, Siqin Bao, Andrew J Bannister, Tony Kouzarides and M Azim Surani.

Int. J. Dev. Biol. (2002) 46: 317320

Expression of the E2F family of transcription factors during murine development.

J C Kusek, R M Greene, P Nugent and M M Pisano

Int. J. Dev. Biol. (2000) 44: 267277

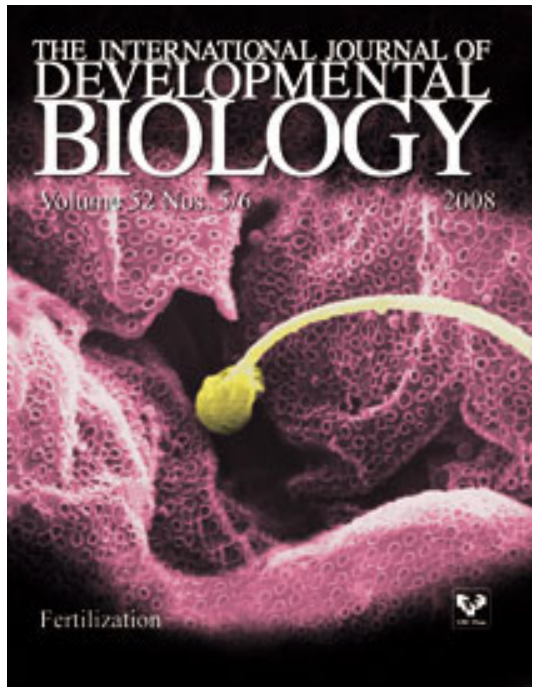

